\title{
المسؤولية الجنائية لمأمور التنفيذ في النظام السعودي
}

\author{
مصطفى محمد بيطار هشام موفق عوض \\ كلبة الحقوق ، قسم القانون ، جامعة الملك عبدالعزيز هوفي
}

المستخلص : تهدف هذه الدراسة إلى تسليط الضوء على جريمة منع التنفيذ من خلال بيان المسائل الأولية المتعلقة

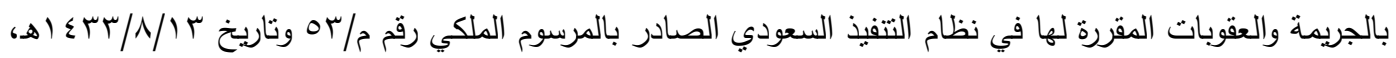
والذي أخضع الموظف العام المكلف بالتنفيذ للمساءلة الجنائية.

وتتناول الدراسة تحديد نطاق مسؤولية مأمور التتفيذ، وبيان الصور المتعددة التي يمكن أن يقوم بها السلوك الإجرامي،

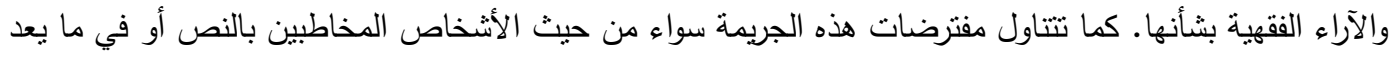

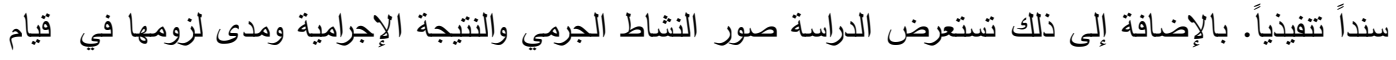

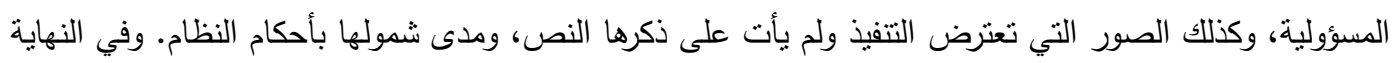

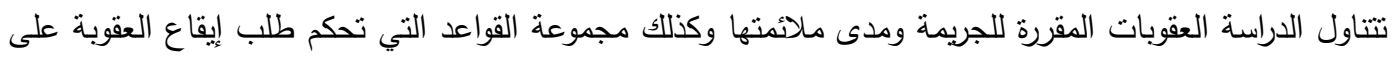
المتهم والجهة المختصة بمحاكته.

أصدرت السند التنفيذي، أو في مكان الجهة التي

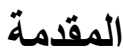

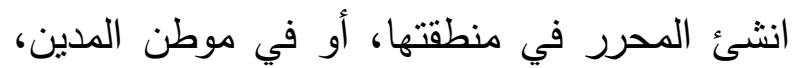
تذهب النظم القانونية في العصر الحديث إلى عدم

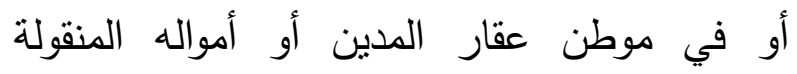
جواز أن يقتضي الثخص حقه بنفسه قهراً حتى ولو الو لون

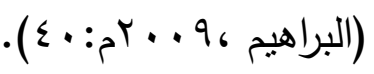
كان بيده سند تتفيذي يؤكد وجود هذا الحق، وفي وحتى عهد قريب، لم يكن النظام السعودي يعرف حال قيامه باستيفاء حقه بنفسه، فإن عمله هذا يعد لئد نظام قاضي التتفيذ، الذي يعتبر قاضياً متخصصاً

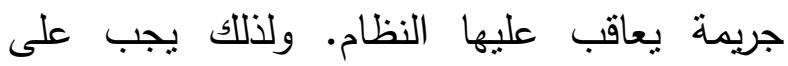

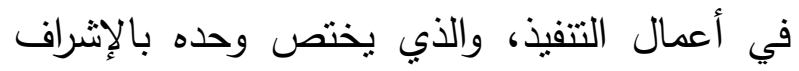
صاحب الحق أن يستعين بالسلطة المختصة إذا والرقابة وحل كافة المنازعات التي تتشأ عن التتفيذ. حيث كان الجهاز الإداري المختص بالتتفيذ يتمنل رغب في تدخلها لإجراء التتفيذ الجبري طبقاً

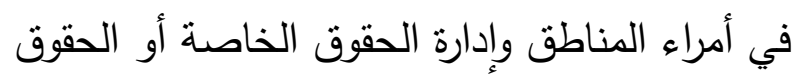
للأوضاع التي رسمها النظام. وتتمنل هذه السلطة في قاضي التنفيذ الذي يوجد في دائرة الدحكمة التي لني 
المختلفة. كما سيؤدي إلى حسن سير العدالة، والتتفيذ على أموال المدين، والحجز على العقار والمنقول بسهولة ويسر على غرار ما هو معدول به الهال

$$
\text { في كثثر من الدول. }
$$

وبموجب نظام التنفيذ السعودي يختص قاضي لني التتفيذ بسلطة التتفيذ الجبري والإثراف عليه، ويعاونه في ذللك من يكفي من مأموري التنفيذ، وتتبع أمامه الأحكام الواردة في نظام المرافعات

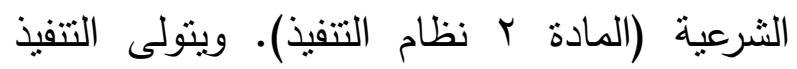
وإجراءاته دائرة خاصة للتنفيذ نوجد في كل محكمة

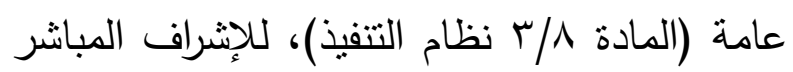

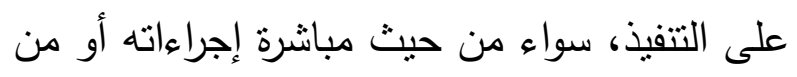

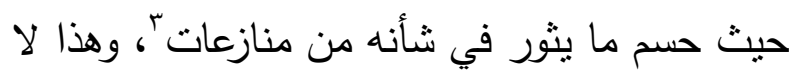
يعني أن القضاة أنفسهم هم الذين يقومون بتتفيذ الأحكام، وإنما يتم ذلك بواسطة مأمور التتفيذ الذي لفي لفئ يتولاه بأمر وإثراف القاضي المختص. ومأمور التتفيذ هو "الثخص الثكلف بمباشرة إجراءات

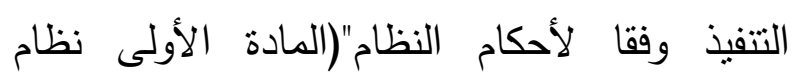
التتفيذ). ويحتاج قاضي التتفيذ إلى طاقم إداري مؤهل؛ بمسميات وظيفية عديدة، كمأمور التتفيذ، والكتبة، إلى مولة ومأمور الصندوق، وأمين حساب التنفيذ وخزينته.

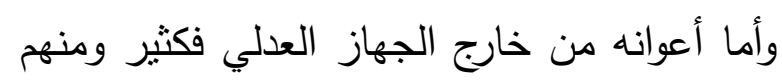
على سبيل المثال: مبلغ الاوراق القضائي، ووكيل

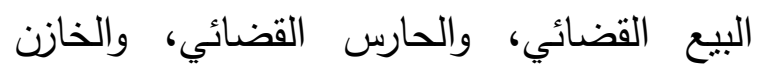
القضائي، وشركات متخصصة تتولى الاثشراف على ولى

" - يختص قاضي التنفيذ بالفصل في منازعات التنفيذ مهما كانت قيمتها، وفقاً لأحكام القضاء المستعجل (المادة الثالثة من نظام التنفيذ

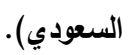

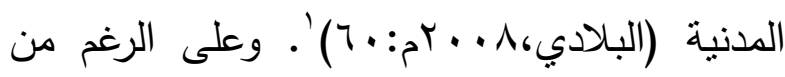

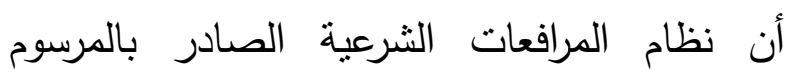

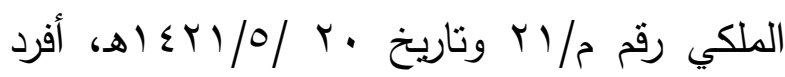

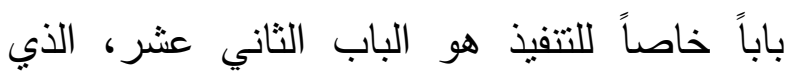

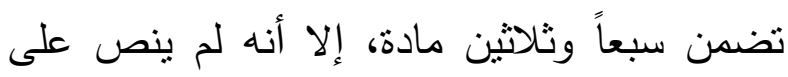
تسمية قاضٍ للتنفيذ ولم يضع أحكاماً تفصيلية توضتح اختصاصاته، بل أثنير إلى قاضي التنفيذ في اللوائح التنفيذية للنظام، على الرغم من أهميته

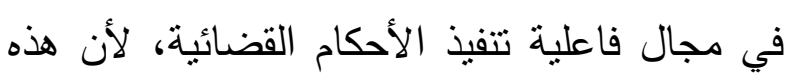

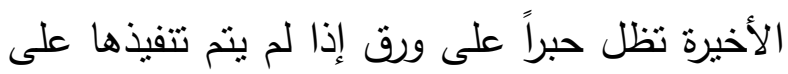

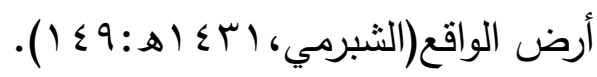

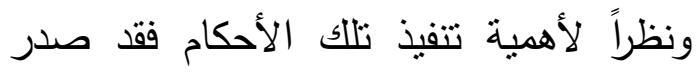
نظام التتفيذ بالمرسوم الملكي رقم م/53 وتاريخ

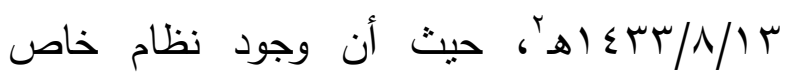

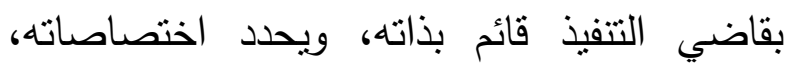
وينظم قواعد التتفيذ الجبري، سيؤدي إلى التخفيف من الأعباء الملقاة على عاتق قضاة المحاكم

1 - من المعلوم أن تنفيذ الأحكام القضائية في الملكة العربية

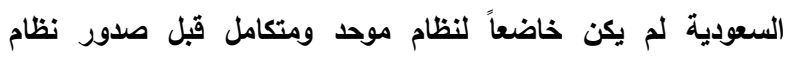

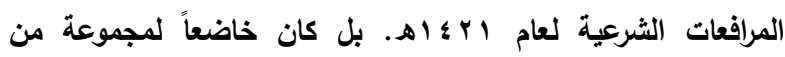
القواع المتنائرة التي لم تكن كافية على الإطلاق لتنظيم عطلية تنفيذ الأحكام القضائية. بل إن تنظيم الأعمال الادارية في الدائئ الثرعية

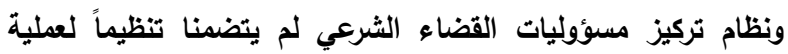

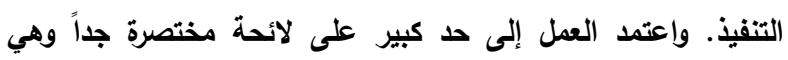

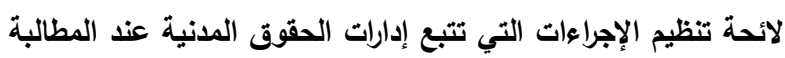

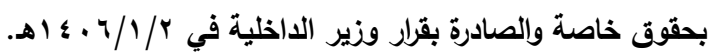

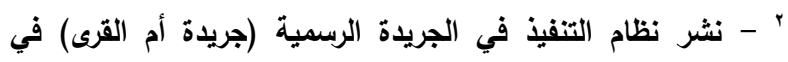

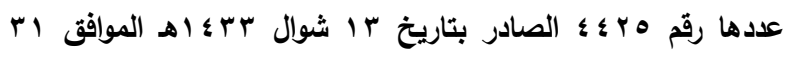

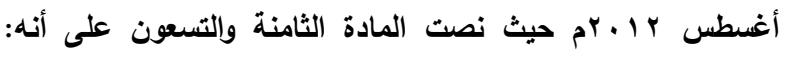

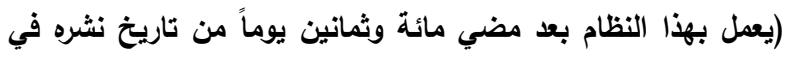

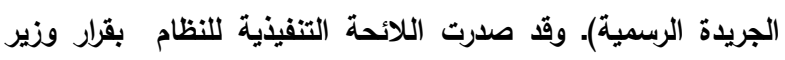

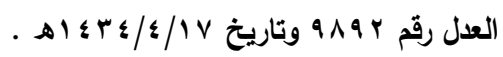


ويبدو عظم مسؤولية مأمور التتفيذ وخطورتها إذا ما قورنت بمسؤولية أطراف الحق في التتفيذ، ذلك أن تعسف الخصم أو مماطلته في التتفيذ وإن كان أمراً مذموماً ويثير مسؤوليته، إلا أنه يمكن اعتباره أمراً

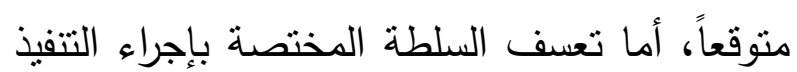
أو انحراف ممثليها عمداً عن طريق الحق فإنه يعد إجراه

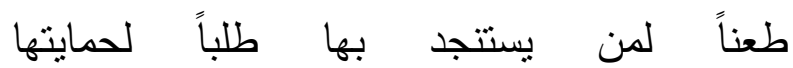

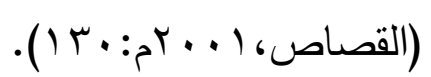

كذلك تتجلى أهمية هذه الدراسة من أهمية عملية

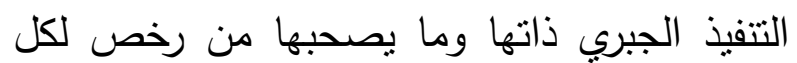
من طالب التتفيذ والمنفذ ضده، فإن مجال التعسف

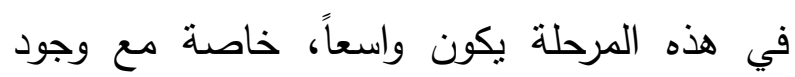
الثغرات القانونية التي يمكن من خلالها التحايل

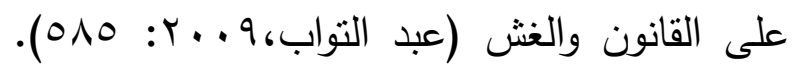
ولعل أخطر مسألة بمكن أن تحدث بفعل التواطؤ بين موظف التنفيذ والمنفذ ضده هي عرقلة التتفيذ

$$
\text { والتباطؤ في إجراءاته. }
$$

كما يكتسب هذا الموضوع أهيتنه من كونه من الموضوعات التي لم يتم تتاولها بعد من قبل الت لهن

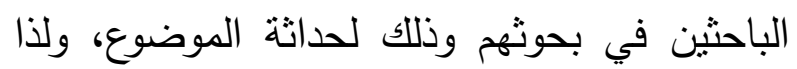
فإن هذه الدراسة تؤدي إلى المساهمة جزئياً في ودي ولئ تحليل علمي في مجال البحوث والدراسات القانونية

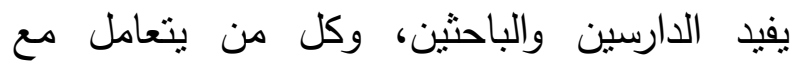
الإجراءات المتعلقة بالتتفيذ، والقائمين على تطبيق نظام التتفيذ الجديد. إثكالية الدراسة : تبرز إثكالية البحث في عدة مسائل نوردها من خلال التساؤلات التالية: من هو الموظف العام في
عملية نسليم المنقولات، ومقدم خدمة تتفيذ من القطاع الخاص (المادة זه نظام التتفيذ). وإيماناً من المنظم في المملكة العربية السعودية بضرورة احترام الأحكام القضائية وضمان تتفيذها بوصفها من الدعائم الأساسية لدولة القانون، وما لفان

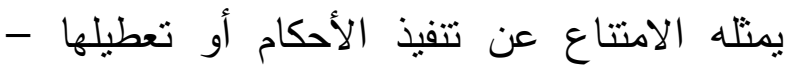
خاصة إذا قام به الموظفون العموميون المختصون بالتنفيذ- من انتهاك صارخ لمبدأ الثرعية الذي الثي تكفل بحمايته، تدخل المنظم السعودي ليحيط الأحكام القضائية بسياج قوي يضمن احترامها ويكفل تتفيذها، فنص في المادة ( (19) من نظام التتفيذ الصادر بالمرسوم الملكي رقم م/ آه وتاريخ

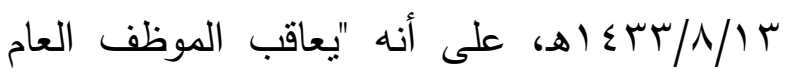
ومن في حكمه، بالسجن مدة لا نزيد عن سبع سنوات إذا ارتكب جريمة منع التتفيذ أو إعاقته، لهند وتعد هذه الجريمة من الجرائم المخلة بالأمانة". أهمية الموضوع : يستمد موضوع المسؤولية الجنائية لمأمور التتفيذ في النظام السعودي أهميته الخاصة من أهمية دور

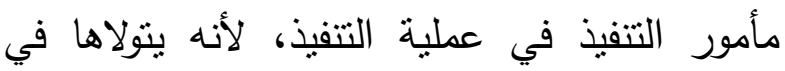
كثير من الأحيان دون تدخل قاضي التنفيذ في سير الإجراءات، بحيث يبدو مأمور التتفيذ وكأنه الممنل

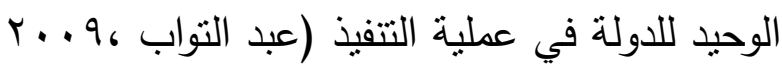

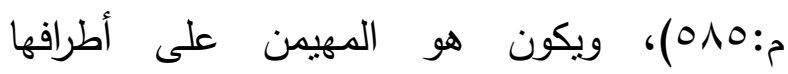
الآخرين، ولهذا كان من الضروري وضع ضون ضوابط

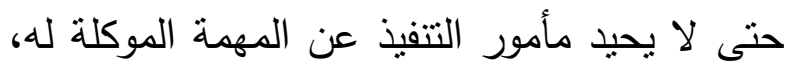
ولا يتعسف في استعمال حقه في القيام بإجراء التنفيذ. 


\section{منهج الدراسة :}

في ضوء الطرح الدقدم لموضوع الدراسة وتساؤلاتها وأهدافها وطبيعة الدراسة، وجب الاستعانة بالمنهج التحليلي الذي يقوم على التفسير والنقد والاستتباط، وذلك بهدف الوصول إلى الددلول الحقيقي للنصوص محل الدراسة. خطة الدراسة : كنا نأمل أن نعالج مسؤولية الموظف العام ومن في حكمه عن منع التنفيذ وإعاقته، وكان هذا هو هدفنا عند اختبارنا للموضوع، ولكن نظراً لأن مأمور التنفيذ هو العامل الرئيس والعمود الفقري لعملية التتفيذ(محمود ،ع . . بم:90)، ولما تثيره كل وظيفة من خصوصية تجعل أحكامها تختلف عن الأخرى، وكذا لخطورة جريمة منع التتفيذ التي تقع من مأمور التتفيذ، وما تثيره دراسة هذه الجريمة من إنثاليات

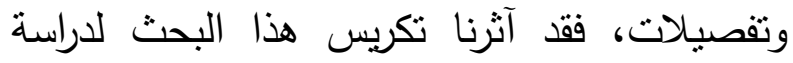
المسؤولية الجنائية لمأمور التتفيذ دون سواه من لان

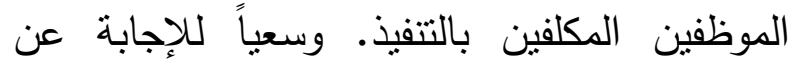
تساؤلات الدراسة المثارة ولتحقيق أهدافها الأساسية، واتساقاً مع المنهجية العلمية المنبعة، قمنا بتقسيم الدراسة إلى مباحث ثلاثة نتتاول فيها:

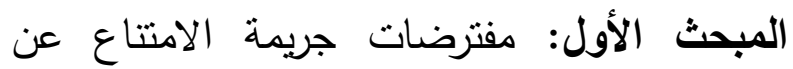
التتفيذ.

المبحث الثاني: أركان جريمة الامتتاع عن التتفيذ، المبحث الثالث: الجوانب الإجرائية والجزاءات التان المقرة للامتتاع.
صدد تطبيق أحكام المادة (19) من نظام التتفيذ؟ وما هي السندات التنفيذية التي يترتب على عدم تتفيذها إثارة مسؤوليته الجنائية؟ وما هي الصور لئه التي يقوم بها الركن المادي؟ وهل لجريمة الامتتاع نتيجة إجرامية؟ وكيف نميز بين الامتتاع عن تنفيذ

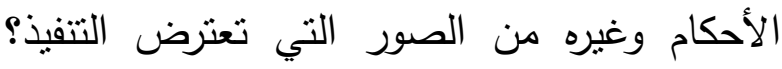
وهل يمكن تطبيق نص المادة (^9) في حالة كون الجهة الحكومية أحد أطراف القضية المتخاصم فيها؟ وما القصد الجنائي الذي تقوم به الجريمة؟ هل هو عام أم خاص؟ وهل نقوم الجريمة في صورة غير عمدية؟ وما هي الجهة المختصة برفع الدعوى؟ والمحكمة المختصة بنظرها؟ وما هي الهي المؤيدات التي استحدثها هذا النظام لإلزام الموظف

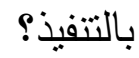

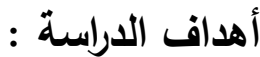
تستهف الدراسة نسليط الضوء على جريمة منع التتفيذ أو إعاقته من خلال بيان المسائل الأولية المتعلقة بالجريمة والعقوبات المقررة لها في نظام التتفيذ السعودي، والأحكام العامة والخاصة لها، والتعريف بمأمور التتفيذ وتحديد مركزه النظامي، وتحديد نطاق مسؤوليته، وبيان الصور المتعددة التي يمكن أن يقوم بها السلوك الإجرامي، وبيان الآراء الفقهية بثأنها، وكذلك تحديد الجهة الدختصة بله بالنظر في المسؤولية الجنائية لمأمور التنفيذ، وطرق تحريك الدعوى. وبهذا تتضح المعالم الرئيسية للمشكلة موضوع البحث، مما يسهم في تلافي أوجه القصور وتقديم الاقتراحات والحلول بشأنها. 
وللاوقوف على مفهوم الموظف العام الذي عنته المادة التاسعة والثمانون، سوف نتتاول مفهوم الموظف العام في القانون الإداري، ثم مفهومه في جريمة الامتتاع عن التتفيذ، والمركز القانوني لمأمور التنفيذ.

$$
\text { الفرع الأول }
$$

مفهوم الموظف العام في القانون الاداري

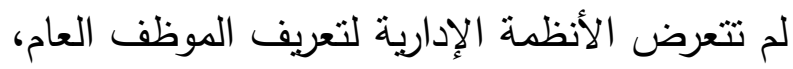
فنظام الخدمة المدنية السعودي الصادر بالمرسوم الملكي رقم م/N؛ وتاريخ · · نظام الموظفين العام الصادر بالمرسوم الملكي رقم

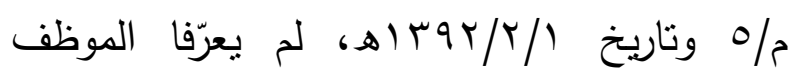
العام. وبغياب تعريف نظامي، كان لابد للقضاء والفقه التصدي لهذه المسألة وإيجاد تعريف للموظف كانف لأبف للفناه

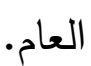
وقد كان للائرة الجزائية في ديوان الدظالم دوراً هاماً في توضيح مفهوم الموظف العام، بقرار جاء فيه

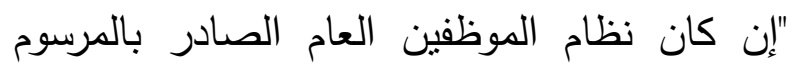

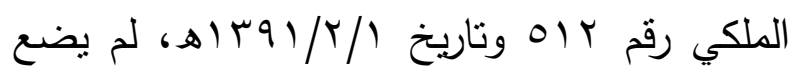

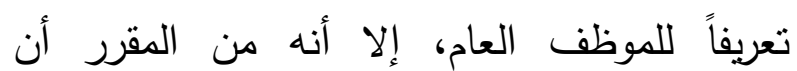
الموظف العام هو الثخص الذي يعهد إليه على الذيه

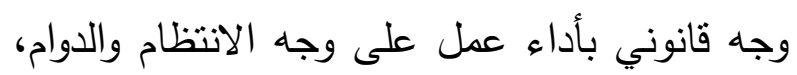
في مرفق عام تديره الدولة أو أحد الأثخاص إداد الأنها

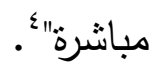
كما ساهم الفقه في إعطاء تعريف للموظف العام، فقد استخلص بعض الثراح من نظام الخدمة

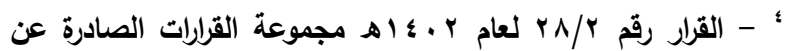

المبحث الأول مفترضات جريمة الامتناع عن التنفيذ تفترض جريمة الامتتاع عن التتفيذ أن يكون مرتكبها موظفاً مختصاً بالتتفيذ، وأن يكون محلها سنداً تتفيذياً مستوفياً جميع مقوماته الموضوعية والثكلية

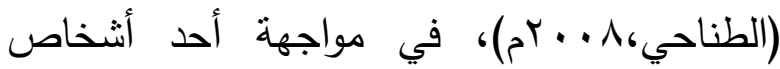
القانون الخاص. وعدم وجود أي من هذه الثروط يترتب عليه عدم وجود الجريمة. وسيتم عرض هذه المفترضات في مطلبين، نخصص الأول للحديث عن وجود موظف عام مختص بالتتفيذ، ونخصص الاول الثاني لدراسة السندات التنفيذية محل الامتتاع.

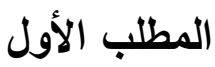

\section{وجود موظف عام مختص بالتنفيذ}

بحسب المادة (19) من نظام التنفيذ السعودي، يشترط أن يكون الجاني موظفاً عاماً، بيد أن المنظم لم يتعرض إلى تعريف الموظف العام الممتنع عن التتفيذ، وهو ذات المسلك الذي نهجه المنظم في سائر جرائم الموظفين العموميين. فالمنظم يقتصر في مجال التجريم خصوصاً في الجرائم التي تقع من فئن الموظف على ذكر مصطلح الموظف دون تحديد المقصود باه، وإزاء عدم وجود نص في الأنظمة الجنائية تحدد المقصود بالموظف العام، فإن النتيجة الطبيعية هي الرجوع إلى مفهوم الموظف العام في

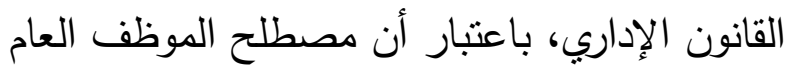

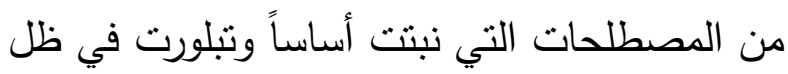
القانون الإداري، ثم نقلها عنه القانون الجنائي

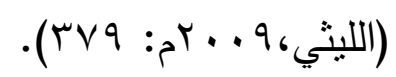




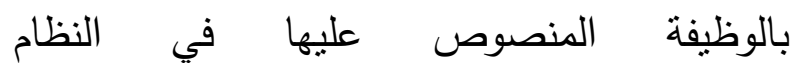

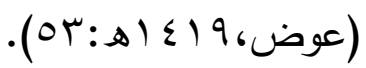

وبتوافر الثروط السابقة يكتسب الثخص صفة الموظف العام، بصرف النظر إن كان معيناً لاى الدولة بصفة دائمة أو مؤقتة، فتظل لله صفة الموظف ما دام أن الوظيفة دائمة وإن كان يقوم بعمله لفترة مؤقتة. الفرع الثاني الموظف العام في جريمة الامتناع لم يقف نظام التتفيذ السعودي عند اعتبار جريمة الامتتاع خاصة بالموظف العام - كما سبق بيانهبل مد نطاقها إلى من هم في حكمه، وهم فئات من الأشخاص لا يتقلدون وظيفة عامة. وقد بينت اللائحة التتفيذية للمادة (1/^9) من نظام التنفيذ بأن أحكام هذه المادة تسري على موظفي الثركات التي تملكها الدولة، أو تشترك في ملكيتها، وكذلك هـاه الجمعيات ذات النفع العام. وهذا يعني مد نطاق التجريم ليشمل إلى جانب الموظفين العامين، بالمعنى الإداري، الموظفين بالقطاع العام، وكذلك الموظفين بقطاع الأعمال وغيرها من القطاعات المملوكة للدولة أو التي تساهم فيها الدولة بأي قدر من رأسمالها، وكذلك موظفي الجمعيات ذات النفع العام. وبشترط في الموظف العام أو من في حكمه أن يكون مختصاً بإجراء التتفيذ، وهذا الثرط وإن لم يرد صراحة في نص المادة (^9) من نظام التنفيذ، إلا أن طبيعة هذه الجريمة تقتضيه، إذ لا يمكن أن أن يسأل شخص عن امتتاع إلا أن يكون مكلفاً بواجب
المدنية واللوائح الوظيفية تعربفاً للموظف العام بأنه "الثخص الذي يشغل إحدى الوظائف العامة

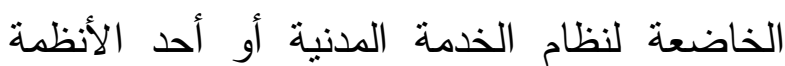
الوظيفية الخاصة كنظام الوزراء أو نظام القضاء الإداري أو لائحة المستخدمين ونحو ذلك، وذلك بالثروط والمؤهلات المطلوبة لشغل أي من هذه

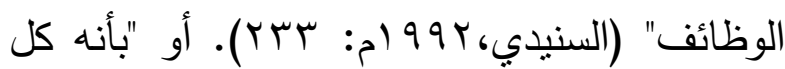
من يعمل بصفة دائمة أو مؤقتة في مرفق عام تديره

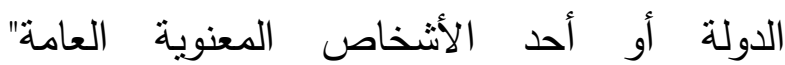

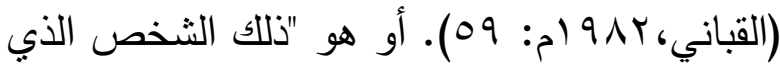
يعهد إليه بعمل دائم في خدمة مرفق عام تديره

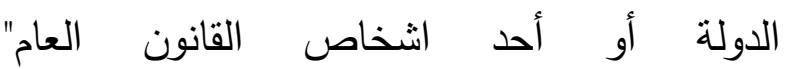
(الطماوي، 907 (م: ج • Y). ويرى الفقه أنه يجب أن تتوافر ثلاثة شروط لاعتبار الثخص موظفاً عاماً وهي: 1-أن يكون العمل في خدمة مرفق عام أو مصلحة عامة تديرها الدولة أو السلطات الإدارية بطريق

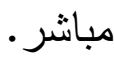
r-أن يكون قائماً بعمل دائم، أي أن نكون الوظيفة وواجباتها داخلة في نطاق المرفق ومقرة بصفة دائمة، يستوي بعد ذلك أن يشغلها الثخص بصفة دائمة أو مؤقتة، كما ويستوي أن يكون العمل مأجوراً أو غير مأجور، فالأجر ليس شرطاً للوظيفة

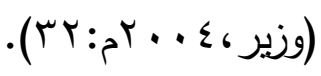
r-أن يكون تعيينه من سلطة تملك ذلك نظاماً، أي أن يكون التحاق الموظف بالوظيفة قد تم بالثروط والأوضاع المقرة نظاماً، ووفقاً لأداة الالتحاق 
المدنية عما ينجم عن إجراء أو عدم إجراء التتفيذ

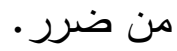

يذهب جانب من الفقه إلى أن المأمور وكيل لطالب التتفيذ وذلك لأن المأمور إنما يقوم بهذا التتفيذ بناء على توجيه الخصم لهذا الإجراء، على أساس أنه

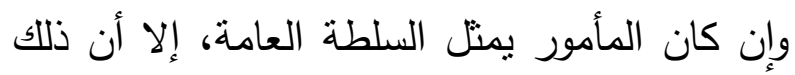
لا ينفي أن له صفة أخرى، وهي أنه بمثابة وكيل عن الطالب لأنه يقوم بالتتفيذ بناء على طلب الدائن

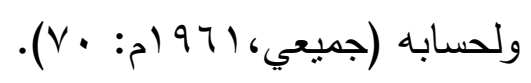

بينما يرى فريق آخر أن مأمور التتفيذ في قيامه بالتنفيذ يؤدي واجبه كموظف عام يلتزم من قبل

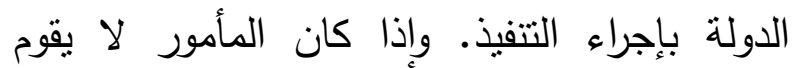
بالتتفيذ إلا بناء على طلب الدائن، فليس معنى هذاء أن هناك علاقة وكالة بينه وبين المأمور، وإنما لألماء معناه فقط أن الطلب يعتبر مفترضاً لقيام مأمور

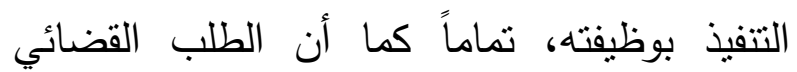
يعتبر مفترضاً لقيام القاضي بوظيفته، ولم يدر بخلد أحد القول بأن القاضي وكيل عن المدعي (والي

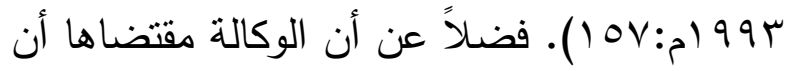
يقوم الوكيل بالعمل بناء على تعليمات الموكل،

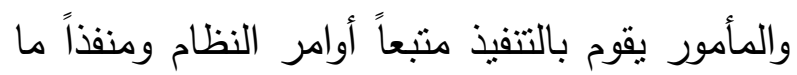

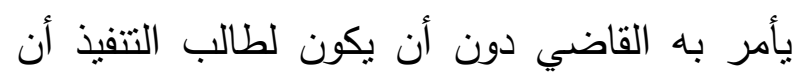
يصدر إليه أية تعليمات في هذا الخصوص (ابراهيم

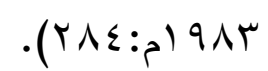
وفي اعنقادنا أن اعتبار مأمور التتفيذ وكيلاً عن

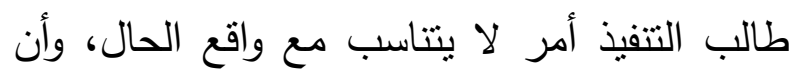

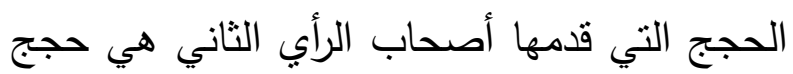
مقنعة. فنحن أمام موظف عام يقوم بالواجب الذي لئي
قانوني يلزمه بالقيام بالعمل، والموظف المختص

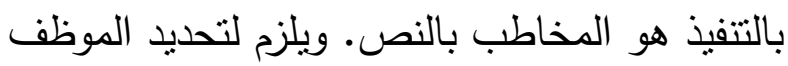
المختص الرجوع إلى القوانين المنظمة لإدارات الدولة ومصالحها. وعلى أية حال، لا يشترط أن الن الن النين

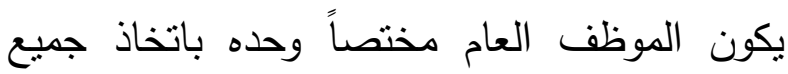

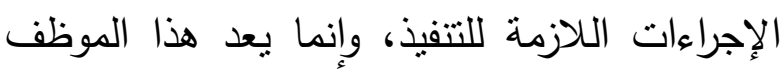
مسؤولاً ولو كان يثاركه في إتمام عملية التنفيذ

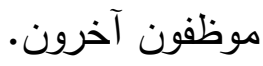

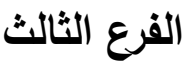
المركز القانوني لمأمور التنفيذ بالنظر إلى صلاحيات مأمور التتفيذ، نجد أن

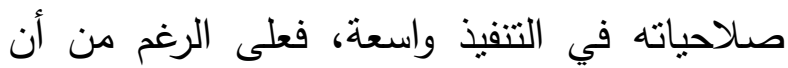

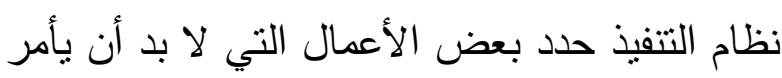
بها قاضي التتفيذ، إلا أنه نرك لمأمور التتفيذ كثيراً

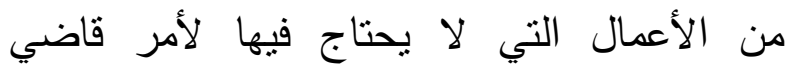
التتفيذ، فهو الذي يتولى الإجراءات اللازمة لتنفيذ لأنياج

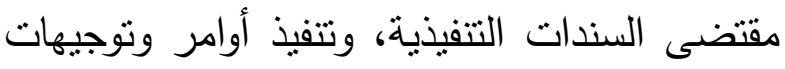
قاضي التتفيذ، ومن ضمنها إجراءات الحجز على ولى العين أموال المدين، ووضع اليد عليها، وبيعها بالمزاد العلني. وإذا كانت أهمية دور مأمور التتفيذ في القيام

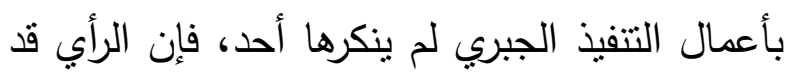

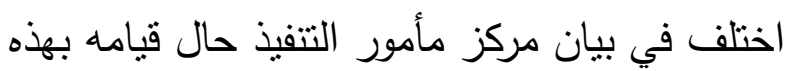

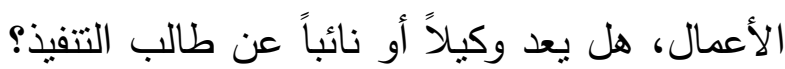
أم أنه موظف عام يقوم بما تمليه عليه واجبات

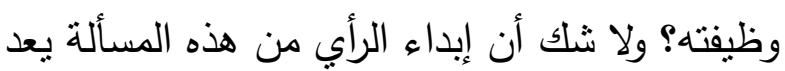
مدخلاً هاماً في تحديد ضوابط مسؤولية المأمور 
التتفيذية، والتي يمكن تصنيفها إلى سندات قضائية وسندات غير قضائية:

سندات التتفيذ القضائية: وهي السندات التي تصدرها الجهات القضائية أو يشترط لتنفيذها مصادقة الجهات القضائية المختصة، وذللك الكيات كالأحكام والقرارات والأوامر التي تصدرها المحاكم، أو محاضر الصلح الني تصادق عليها المحاكم

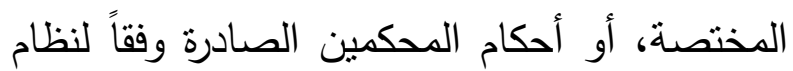
التحكيم، أو الأحكام الأجنبية. سندات التنفيذ غير القضائية: وهي التي يعطيها النظام قوة السند التفيذي بذاتها دون اشتراط مصادقة الجهات القضائية عليها، وفقاً للأنظمة ذات العلاقة وذلك كالأوراق التجارية، والعقود الموثقة، أو المحررات العادية التي بصادق علية التيها

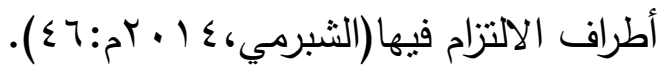
وقد نصت المادة التاسعة من نظام التتفيذ على بعض شروط صحة اعتبار السندات التنفيذية وقابليتها للتنفيذ بقولها: "لا يجوز التتفيذ الجبري إلا بسند تتفيذي لحق محدد المقدار وحال الاداء". ويتضح من ذلك أنه يتعين أن يتوافر في السند التنفيذي الثروط الآتية:

الثرط الأول: أن يكون السند التتفيذي متضمناً

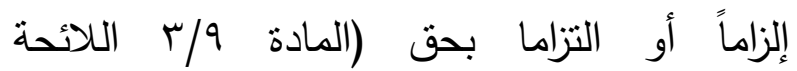
التنفيذية)، بمعنى أن يكون سنداً إيجابياً لا سلبياً،

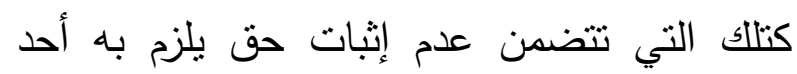
طرفي السند التتفيذي أو الني يحكم فيها مثلاً بصرف النظر عن دعوى المدعي، أو الحكم ببراءة

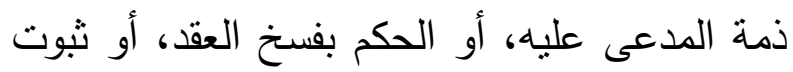

تمليه عليه مقتضيات وظيفته. وإذا كان مأمور

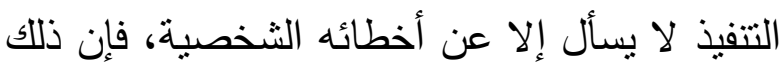
ليس بسبب كونه وكيلاً عن طالب التتفيذ، ولكنه بسبب كونه موظفاً يؤدي واجبه الذي لا يستطيع أن يتقاعس عنه. ويترتب على هذا القول، أن مسؤولية

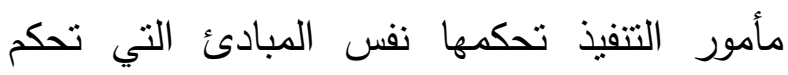
مسؤولية غيره من الموظفين العموميين (والي لهوني (10:م) (1994) المطلب الثاني

السندات التنفيذية التي يعاقب على عدم تنفيذها

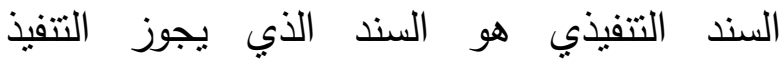
بمقتضاه، والسندات التتفيذية التي يعاقب على عدم تتفيذها أو إعاقة تتفيذها ليست محصورة فقط بالأحكام والأوامر الصادرة عن المحاكم، والقرارات الصادرة عن اللجان القضائية وشبه القضائية، وإنما تثمل إضافة لذلك سندات تتفيذية غير قضائية. ولابد للمعاقبة عن منع تتفيذ هذه السندات من إبلاغها إلى مأمور التتفيذ، وأن تكون في مواجهة

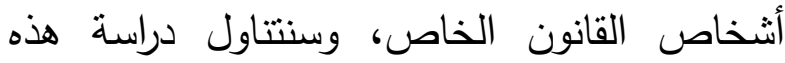
الثروط في ثلاثة فروع. الفرع الأول شروط السند التنفيذي

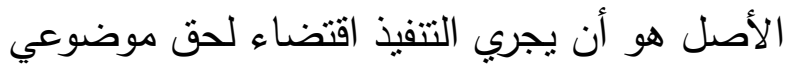
للائن قبل مدينه. ويشترط نظام التنفيذ أن يتم تأكيد هذا الحق الموضوعي بواسطة عمل قانوني يتخذ

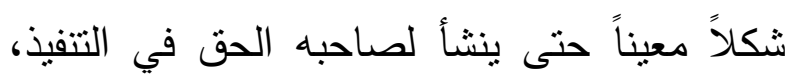
ويطلق على هذا العمل القانوني "السند التتفيذي". وقد عددت المادة التاسعة من نظام التتفيذ السندات 
الثرط الخامس: أن يكون الحكم أو الأمر القضائي

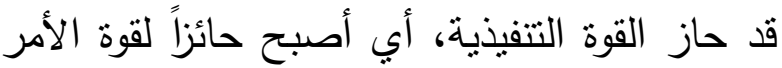

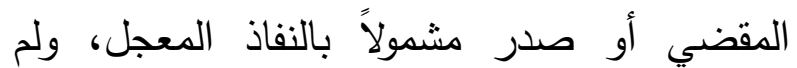
يصدر حكم أو أمر من جهة قضاء مختصة بوقف الون التتفيذ بناءً على طعن أو منازعة في التتفيذ (المادة • 1 نظام التتفيذ، المادة/1 اللائحة التنفيذية).

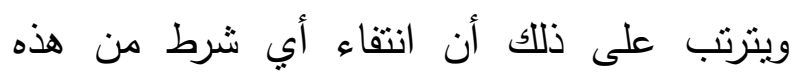
الثروط يؤدي إلى فقدان السند لقوته التنقيذية، وبالتالي لا يصلح أساساً كافياً لقيام الجريمة بحق لقونه

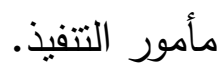
الفرع الثاني

\section{صدور أمر من قاضي التنفيذ}

ينبغي لقيام جريمة الامتتاع عن التنفيذ، بالإضافة إلى ما سبق ذكره، صدور أمر من قاضي التتفيذ لمأمور التتفيذ قبل إجراء التنفيذ.

فالقاعدة أن مأمور التتفيذ لا يبدأ التتفيذ الجبري إلاه

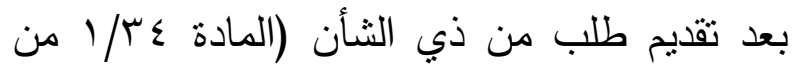

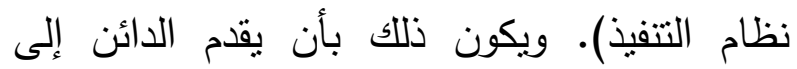
قاضي التتفيذ طلباً بإجراء التتفيذ مرفقاً به صورة من بن السند التتفيذي عليها الصيغة التتفيذية التي يشترطها المنظمْ. فإذا ما قدم الطلب إلى قاضي التتفيذ على لئل

○- نص نظام المرافعات الثرعية السعودي الصادر بالمرسوم الملكي رقم

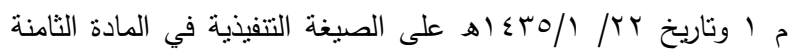

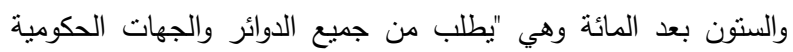

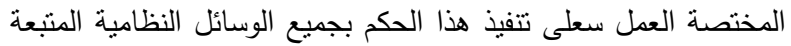
ولو أدى إلى استعمال القوة الجبرية عن طريق الثرطة". والتي تقابل (المادة ع ץ/ من اللائحة التتفيذية لنظام التنفيذ السعودي). ويتحقق قاضي التتفيذ من وجود الصيغة التتفيذية على السند التتفيذي الوارد في التي

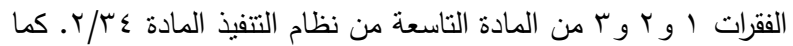
ويتحقق من استيفاء السندات التتفيذية الاخرى -في الفقرات ؛ و وه و و 7 و > و من المادة التاسعة، الثروط النظامية، ويضع خاتم التتفيذ عليها،
الملكية، مما لا تتطلب إلزام المحكوم عليه بالقيام بعمل معين، أو أداء حق ثابت، والذي يطلق عليه قضاء الترك.

الثرط الثاني: أن يكون الحق الملزم به بالسند التتفيذي محدد المقدار، فلا يكون إلزاما بحق قابل للزيادة والنقصان كالحكم بالاستحقاق في تركة أو ريع وقف أو جبر ضرر دون تحديد لمقدار ذلك الحق، الأمر الذي من شأنه أن يأذن بحصول نزاع جديد عند التفيذ عن القدر اللازم والكافي لتتفيذ ذلك

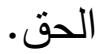
الثرط الثالث: أن يكون الحق الذي تضمنه السند التتفيذي حال الأداء عند التقدم بطلب تتفيذ السند التنفيذي، فلا يجوز التنفيذ الجبري لسند تتفيذي يتضمن حقاً مؤجلاً إلى أجل لم يحل بعد، أو معلقاً على شرط لم يقع بعد، فلا يجوز التتفيذ إلا إذا كان

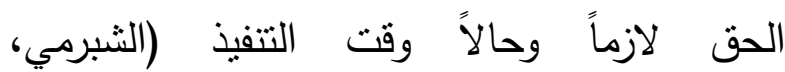
ع ا • rم: ع ع). وإذا خلا السند التفيذي من بيان ميعاد الاستحقاق، اعتبر حال الأداء، وللمعترض بدعوى عدم حلول الأجل، التقدم بدعوى لدى قاضي الدي الموضوع، ولا يوقف التنفيذ مالم يرد قرار من قاضي الموضوع بذلك (المادة 1/9 اللائحة التتفيذية لنظام التنفيذ). الشرط الرابع: عدم مخالفة السند التتفيذي لأحكام الشريعة الإسـامية أو النظام العام للاولة. فكل سند تتفيذي مخالف للثرع كله أو بعضه، يجب عدم تتفيذ المخالف منه، وعند اعتراض طالب التتفيذ، يصدر القاضي قرارا بذلك يخضع لطرق الاستئناف (المادة 9/ ( اللائحة التنفيذية لنظام التنفيذ). 
ويثور التساؤل لمعرفة فيما إذا كان نص المادة سالفة الذكر ينطبق على الموظف العام إذا ارتكب جريمة منع التتفيذ أو إعاقته لحكم صادر ضد

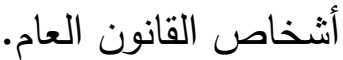

يرى البعض أن نص المادة (9 (^) ينطبق على النى الموظف العام إذا ارتكب جريمة منع التنفيذ أو لري إعاقته لحكم صادر ضد أشخاص القانون

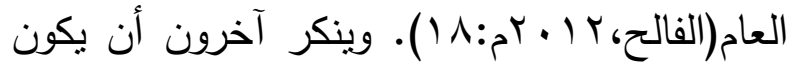
هذا مقصد واضعي النظام، حيث لم يتطرق نظام التنفيذ السعودي للجهات الحكومية فيما يخص الموضوع إلا في ثثلاثة مواضع، في المادة (l/Yl/)، استثنى أموال الدولة من التتفيذ، وفي المادة (V) أشار إلى شمول أحكام التنفيذ المباشر للأشخاص المعنوية إلا أنه حصرها في أشخاص القانون الخاص وأخرج أثخاص القانون العام، ثث في المادة (^9)، عاقب الموظف العام إذا منع التتفيذ أو اعاقه وجعلها من الجرائم المخلة بالأمانة،

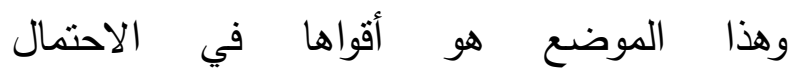

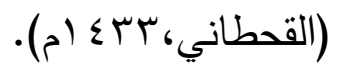
وفي اعتقادنا أن الرأي الأخير أقرب للصواب، حيث أن موضع المادة (^^) في نظام التنفيذ يثير إلى شموله للموظفين الذين يعيقون التفيذ الجبري على الأشخاص الخاصة دون العامة، أو بمعنى آخر أنه لا يقصد به حالة التتفيذ على الجهة الحكومية. المبحث الثاني

\section{أركان جريمة منع التنقيذ}

تقوم جريمة منع التتفيذ أو إعاقته على ركنين، الأول هو الركن المادي والمتمنل في سلوك الجاني حيث
النحو السابق يجب على المأمور القيام بالتنفيذ، فإذا امتتع عن القيام بمهامه دون الاستتاد إلى حجة قانونية تبرر ذلك كان مسؤولاً عن امتتاعه. وبالتالي لا تقوم مسؤولية مأمور التتفيذ في حال كان عدم قيامه بالحجز الذي طلب منه راجعاً إلى عدم تسلمه السند التنفيذي أو الأمر بالحجز من طالب الحجز. وعليه يلزم لمساءلة مأمور التنفيذ المتهم بالامتتاع عن التنفيذ، أن يتم إبلاغه بالسند التنفيذي، وأن يكون هذا السند مستوفياً جميع مقوماته الموضوعية والثكلية كما ذهبت أحكام القضاءّ. وإذا تمسك الموظف بعدم إعلانه بالسند التنفيذي فإنه يجب على المحكمة أن ترد على هذا الدفع في حكمها، وإلا كان حكمها مشوباً بالقصور لأنه من الدفوع الجوهرية. وقد ذهبت إلى ذلك محكمة النقض المصرية حيث قضت بأن الدفع بعدم إعلان السند التتفيذي من الدفوع الجوهرية، وأن عدم مواجهته

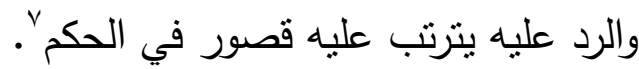
الفرع الثالث أن تكون السندات في مواجهة أشخاص القانون

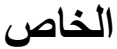
لا خلاف على أن الموظف العام الذي يمتتع عن تتفيذ الأحكام القضائية الحائزة لقوة الثيء المقضي به، الصادرة ضد أشخاص القانون الخاص، مشمول بأحكام المادة التاسعة والثمانون من نظام التتفيذ.

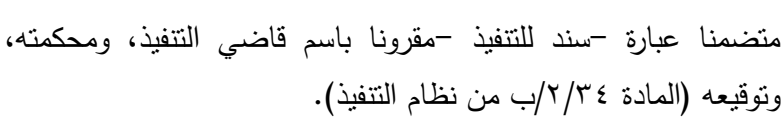

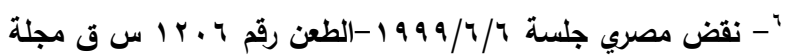

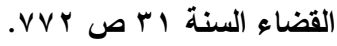

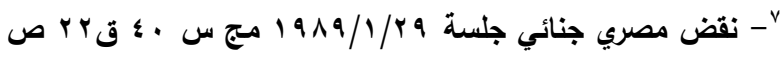




$$
\text { أولاً: مفهوم الامتتاع وشروطه }
$$

يذهب بعض شراح القانون إلى تعريف الامتناع بأنه "إحجام عن أداء واجب أو عمل يفرضه القانون"

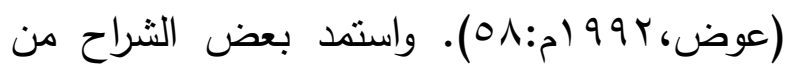

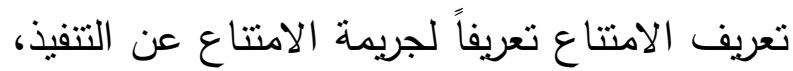

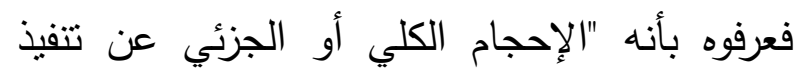
حكم قضائي واجب التتفيذ من جانب الموظف العام المكلف قانوناً بتتفيذه بقصد عدم وصول الحق هن

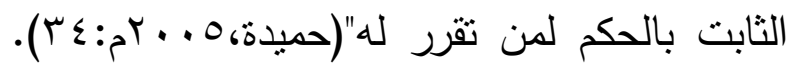

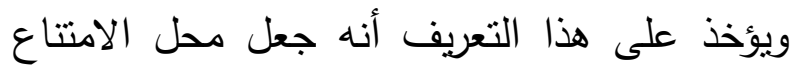

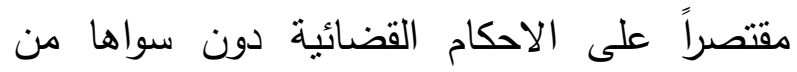

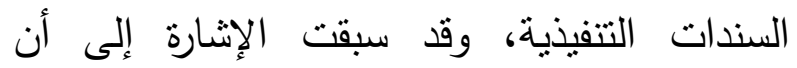

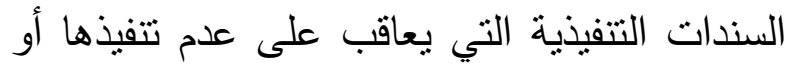
إعاقة تتفيذها ليست محصورة فقط بالأحكام الصادرة عن المحاكم والقرارات الصادرة عن اللجان القضائية وشبه القضائية، وإنما تشمل إضافة لذلك سندات تنفيذية غير قضائية وفقاً للمادة التاسعة من نظام التتفيذ. وعليه يمكن تعريف الامتتاع عن التتفيذ بأنه: الإحجام الكلي أو الجزئي عن تتفيذ سند تتفيذي

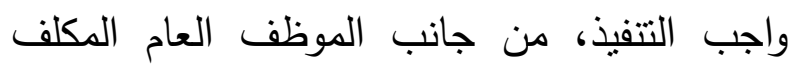

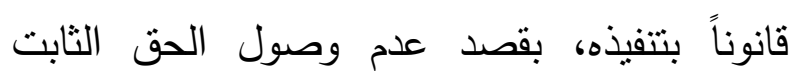
بالحكم لمن تقرر له.

ويتضح من التعريف، أنه يتطلب لقيام جريمة الامتتاع عن النتفيذ توافر شروط جرائم الامتتاع لئه عموماً، فيشرط إحجام الجاني عن إنيان فعل ايجابي معين، وهو القيام بالتتفيذ الجبري على أموال التيان المدين، وأن يوجد واجب قانئ بالني يلزمه بالقيام
يظهر في شكل احجام كلي أو جزئي عن التتفيذ أو

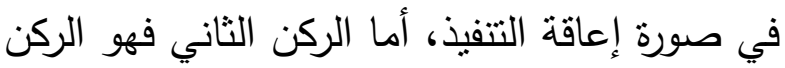
المعنوي المتمثل في القصد الجرمي. وسنعمل فيما يلي-على دراسة هذه الأركان في مطلبين:

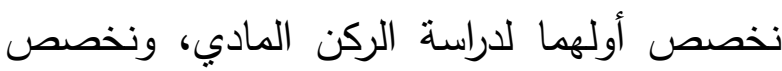
الثاني لدراسة الركن المعنوي.

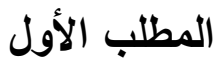

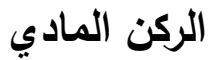

يقصد بالركن المادي الصورة المادية للجريمة كما

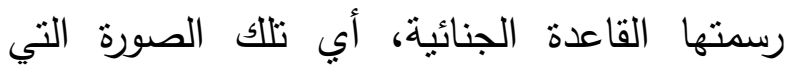
يتخذها السلوك الإنساني مادياً حتى يمكن وصفه الحنه بالجريمة. ويتمثل الركن المادي للجريمة موضوع

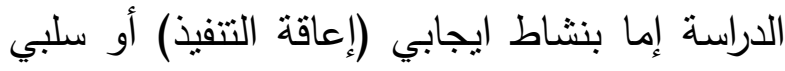
(منع التنفيذ). ويترتب على هذا النشاط أثر يتهنل

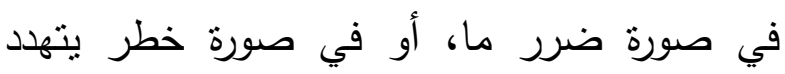

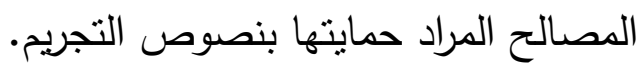
وسوف نفصل الكلام عن صور الركن المادي للجريمة في فرعين: الأول للنع التتفيذ، والثاني لإعاقة التنفيذ. الفرع الأول منع التفيذ التيذ الامتتاع يمتل الصورة السلبية أو الثكل السلبي

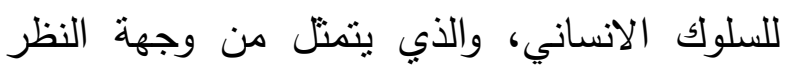
القانونية بتوقف عن الحركة، أو القيام بحركة مغايرة

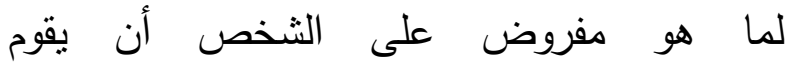

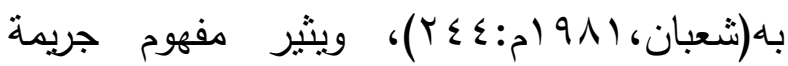
الامتتاع عن التنفذذ وشروط قيامها وكذا النتيجة الإجرامية عديد من النساؤلات نتتاولها فيما يلي: 
الامتتاع البسيط، وهو الامتتاع الدجرد الذي لا

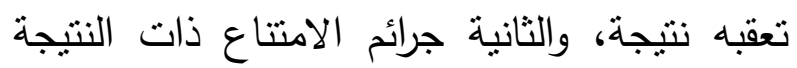
والتي يتطلب لقيام ركنها المادي أن يعقب الامتتاع

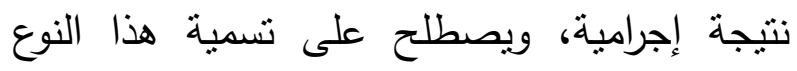

ويختلف الامتتاع أو الإحجام عن الترك في صورة النتيجة التي تترتب على كل من هاتين الجريمتين،

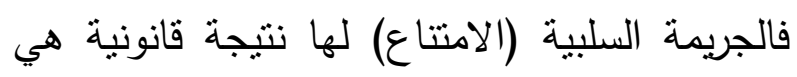
المساس بالمصلحة المحمية وليس لها نتيجة مادية، ومثالها إحجام الثاهد عن أداء الثهادة التي كلف الثهائه بأدائها، وامتتاع القاضي عن الحكم في الدعوى، وإحجام الملتزم بالنفقة عن الوفاء بالتزامه. ويعني

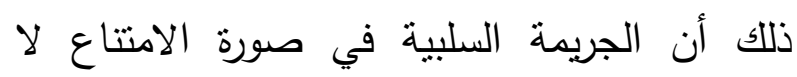
يفترض ركنها المادي سوى ذلك الإحجام. أما الجريمة الايجابية التي تقع بطريق الترك فتترتب

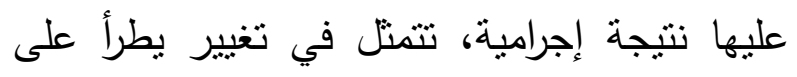

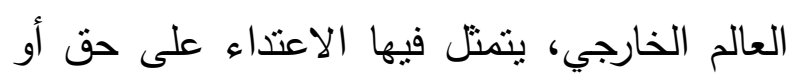

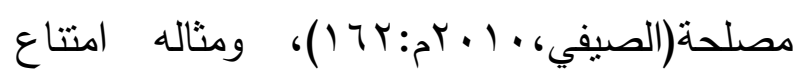

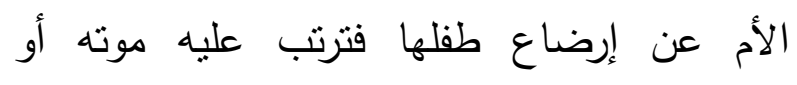
الإضرار بصحته، وامتتاع حارس سجن عن تقديم

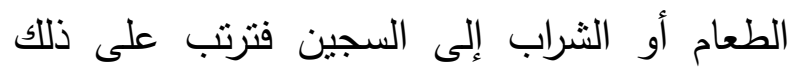

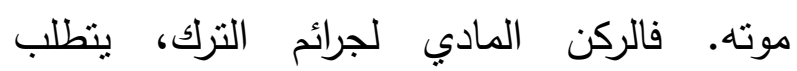
بالإضافة إلى الامتتاع أن تحدث نتيجة إجرامية، وأن يثثت نوافر علاقة سبيية بين الامتتاع وهذه الإن النتيجة. - ان

ونظراً لأهمية النتيجة وما لها من أثر في العقاب فإن ذللك يقتي أن نحدد إلى أي الطائفتين تتنمي لأني

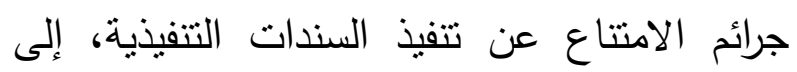

بالعمل، وهذا الواجب القانوني الذي ينرتب على

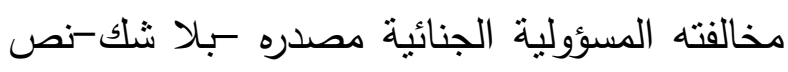

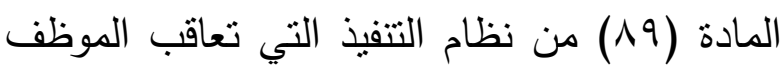

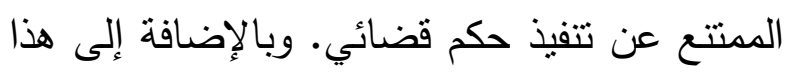
المصدر هناك الصيغة التتفيذية للحكم والتي تلزم الموظف في القيام بالتتفيذ. ولا بد أخيراً من كون هذا الامتتاع إرادياً، بمعنى أن بالن

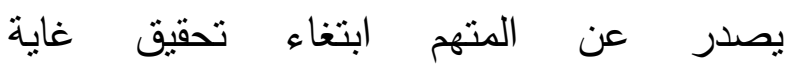

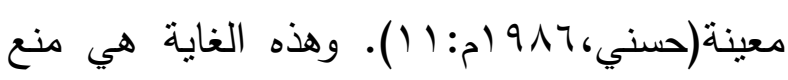
استيفاء الدائن حقه الثابت في السند من الددين قهراً عنه. ولا يهتم القانون بالامتتاع ولا يرتب عليه آثاره ما لم يؤسس هذا الامتتاع على إرادة. فالإرادة إذاً عنصر جوهري في الامتتاع، ولكي تتتج آثارها في تكوين السلوك الإجرامي لاى الجاني لا بد أن تكون هناك علاقة سبيية بين إرادة الجاني وبين الفعل لإن لإن الكان السلبي المتمتل في الامتتاع. ثانياً: النتيجة الإجرامية

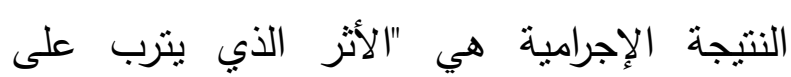
السلوك الإجرامي، وهي العدوان الذي ينال المصلحة أو الحق الذي يقرر له القانون حماية جنائية"

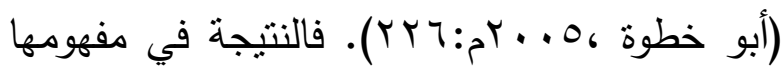
المادي عبارة عن التغيير الذي يحدث في العالم الخارجي كأثز للسلوك الإجرامي، لذا يجب أن ترتبط لئي النتيجة بالسلوك الذي أدى إليها برابطة السبيبة. وهناك جرائم لا يشترط لقيامها تحقق نتيجة معينة،

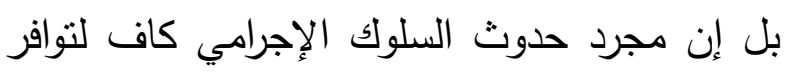

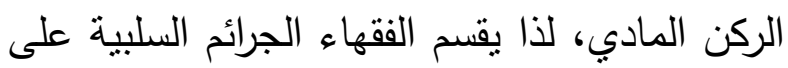
أساس النتيجة الإجرامية إلى طائفتين: الأولى جرائم 
الأثز المترتب على النشاط، وتتمنل هنا في ضرر معنوي وهو الاعتداء على الحق الذي يحميه القانون. وهذا الرأي يأخذ بالمفهوم القانوني للنتيجة

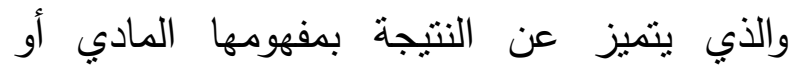
الضرر المادي المترتب على النشاط

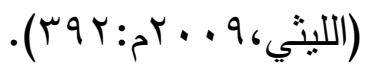
ووفقاً لما سبق، فإننا لا نرى اختلافاً بين الرأيين، فهناك اتفاق على أن جريمة الامتتاع عن التتفيذ هي جريمة سلبية بحتة، وإن كان هنالك اختلاف حول النتيجة فهو اختلاف ظاهري حيث أن الرأي الأول لا ينطلب نرتب نتيجة مادية والرأي الثاني يستلزم وقوع نتيجة قانونية، والنتيجة القانونية ليس لها مظهر خارجي وتتحقق بمجرد مخالفة أوامر

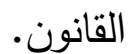
وبناء عليه، فإن امتتاع الموظف المختص بالتتفيذ

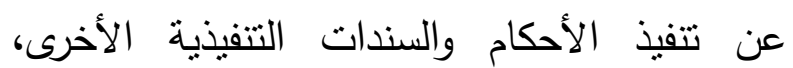
والمنصوص عليها في المادة (^9) من نظام التتفيذ، تعتبر من جرائم الامتتاع المجرد (الإحجام)، وبالتالي فإن الجريمة تكون تامة بمجرد الامتتاع بصرف النظر عن حدوث نتيجة إجرامية معينة

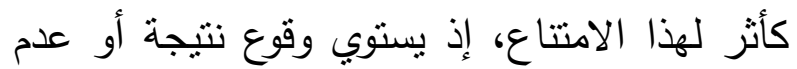

$$
\text { ثالثاً: صور الامتثاع عن الإطلاق. }
$$

يتخذ الامتتاع عن التتفيذ صور متعددة، لعل أهمها

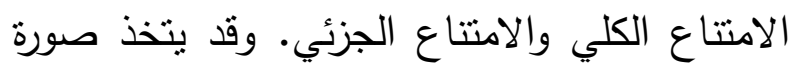

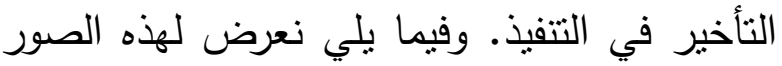

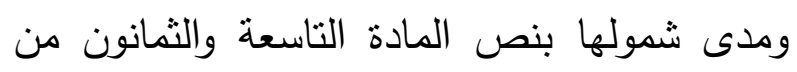

جرائم الامتتاع البسيط أم إلى جرائم الترك؟ وهل

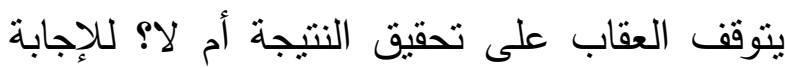
عن هذا التساؤل، نرى أنه من الضروري بيان الآراء الفقهية، ثم توضيح رأينا في الموضوع. انقسم الفقه في صدد هذه المسألة إلى اتجاهين: الأول يرى بأن جريمة الامتتاع عن تنفيذ الاحكام تقوم تامة بمجرد الامتتاع، وبصرف النظر عن النان حدوث نتيجة معينة كأثر لهذا الامتتاع، إذ يستوي

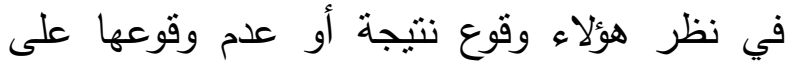

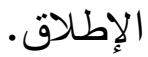

وييرر أنصار هذا الرأي موقفهم بأن الوظيفة تقرض الإط المان على الموظف الالتزام بالقيام بالعمل المطلوب منه القيام به، وفي حال امتتاعه عن القيام بهذا العمل فإنه يكون أهلاً لتطبيق العقوبة عليه، ذلك أن الموظف ملزم قانوناً بأن يقوم بهذا العمل حتى لا لا لهابها ينثئ عن امتتاعه عن القيام به واستخدام ما له من لهن

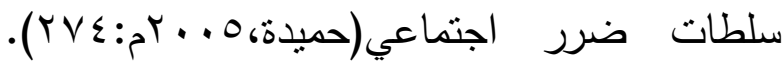
فهؤلاء يرون أن امتتاع الموظف عن القيام بالعمل المكلف به قانوناً يفترض احتوائه على نتيجة إجرامية، تتمنل في الضرر الذي ينشئ حتماً عن مخالفة أوامر الثارع، ولذا يجب أن يكون محلاً لتوقيع العقاب عليه دون البحث في مدى توافر هذه النتيجة من عدمه. بينما يذهب رأي آخر إلى تطلب وقوع النتيجة كأثر

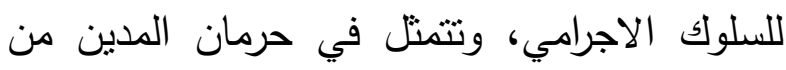

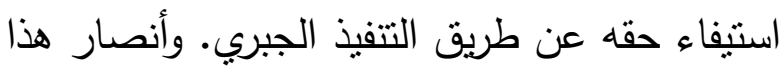
الرأي يأخذون بالمدلول القانوني للنتيجة، ويستتدون

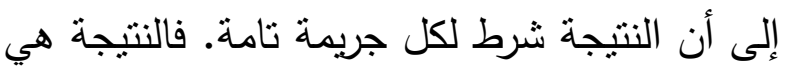


الثاني: التزام المأمور باتخاذ ما يلزم من الوسائل عن حدوث مقاومة مادية تعوق التتفيذ، إذ يجب

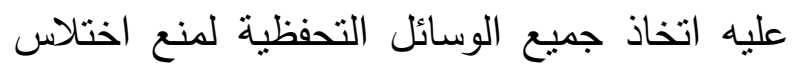

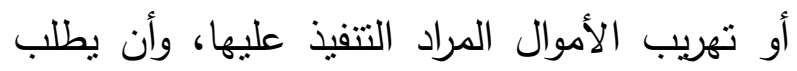

معونة القوة العامة لإجراء التتفيذ بالقوة الجبرية. الثالث: أن مدة التتفيذ هي المدة التي تتاسب مع ما لإناء يلزم اتخاذه من خطوات عملية نحو التتفيذ، وهذه

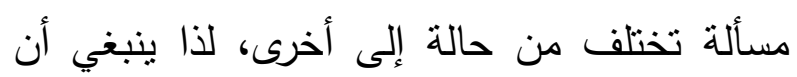
يترك تقديرها للمحكمة التي ستتظر الجريمة. وبناء عليه، يلزم منح الموظف مهلة معقولة لتتفيذ

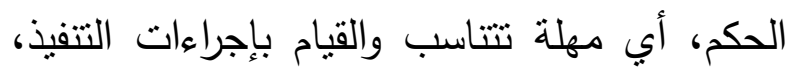

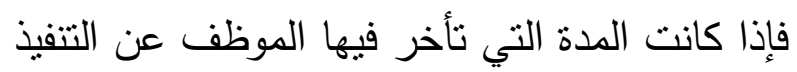

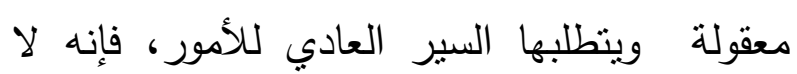

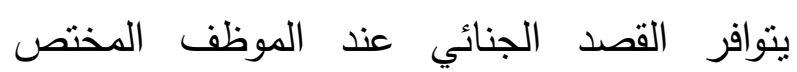

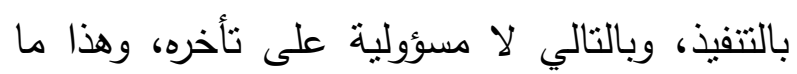
أيدته محكمة النقض المصرية 9. r-التأخير في التتفيذ قد بأخذ الإحجام صورة مماطلة من جانب الموظف فئف

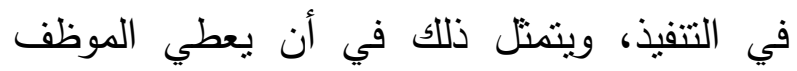

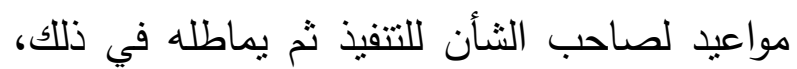

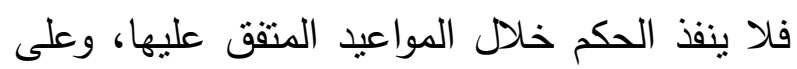

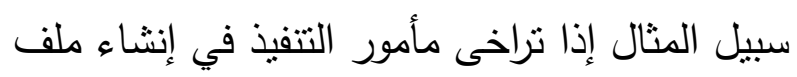

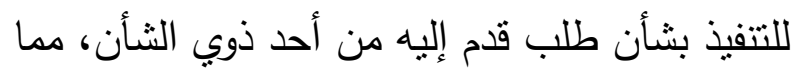
تسبب في تهريب المطلوب الحجز عليه لأمواله

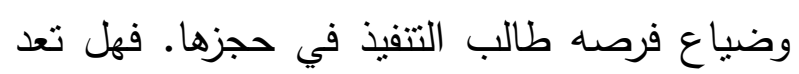

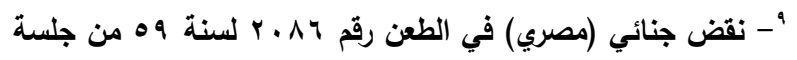
ه
1- إمنع التنفيذ الكلي أو الجزئي تتوافر مسؤولية الموظف عن جريمة الامتتاع سواء

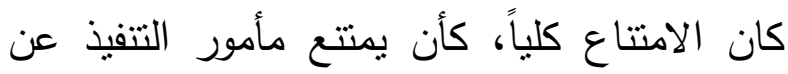
تتفيذ الحكم بكل ما يتضمنه من التزامات، كما لو لو لاعلي

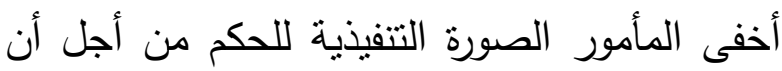

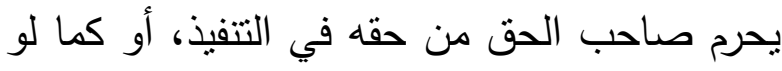
تعدد التأخر في إجابة طلب الدائن نوقيع الحجز

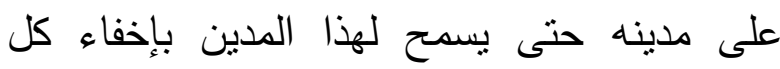

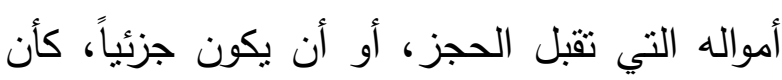

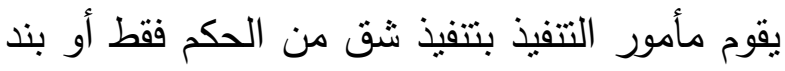

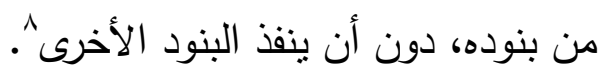

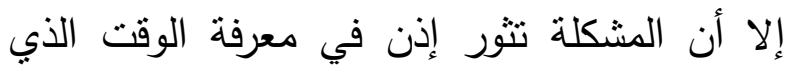
بانقضائه يعتبر الموظف ممتتعاً عن التتفيذ - سيما إذا أخذنا بالرأي القائل إن الامتتاع لا يتطلب حدوث

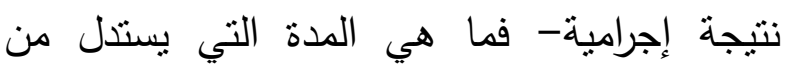
انقضائها أن الموظف سيء النية وممتتع عن التنفيذ؟ خلا نظام التتفيذ ولائحته التتفيذية من مدة بستخل

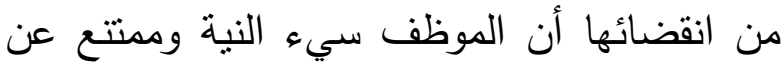

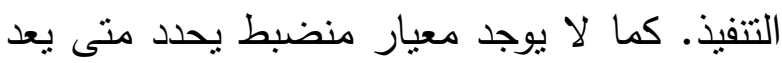

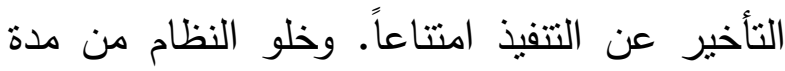
محددة للتنفيذ يفيد باعتقادنا أمور منها: الأول: التزام مأمور التنفيذ بإجراء التتفيذ وفقاً للأوضاع المقررة في النظام متى طلب منه ذلكاء

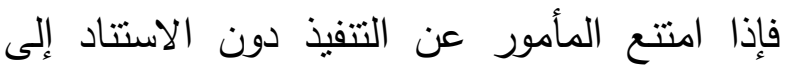
حجة قانونية تبرر ذلك يكون مسؤولاً عن امتتاعه.

^ - هذه الصور ذكرها الفقهاء في صدد الحديث عن جريمة امتناع الإدارة عن تتفيذ الأحكام الإدارية الصادرة ضدها. 
ومع صراحة النص فإننا نعتقد بأن استبعاد المادة

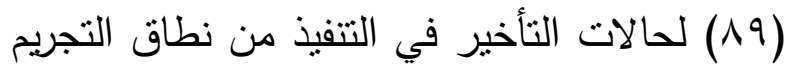
يمنح مأموري التتفيذ الرخصة في التأخير والتراخي في التتفيذ، بل ويجعلهم - إذا ما رغبوا في تعطيل تتفيذ الأحكام سينتهجون أسلوب الثأخير والتباطؤ

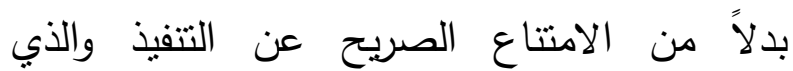
يخضعهم لنطاق التجريم الوارد في المادة (19) من عن نظام التنفيذ. الفرع الثاني إعاقة التنفيذ

سبق وذكرنا بأن جريمة الامتتاع عن التنفيذ هي جريمة سلبية، بكفي فيها اتخاذ الموظف المختص الانس بالتنفيذ موقفاً سلبياً بالامتتاع عن التتفيذ، بعد إبلاغه بالسند التتفيذي ودون سبب مشروع. أما جريمة إعاقة التتفيذ فهي جريمة إيجابية، تستلزم وقوف الموظف المختص بالتتفيذ أو من له الرئاسة عليه موقفاً ايجابياً من التتفيذ، يترتب عليه عرقلة التهن التتفيذ بتعطيله أو وقف تتفيذه. ووسيلة ذلك أن يأتي

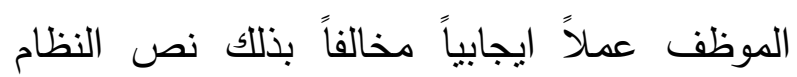
الذي ينهى عن إتيانه وينص على عقابه، مما يتوافر فيه تعريف الجريمة الايجابية فيضع الموظف

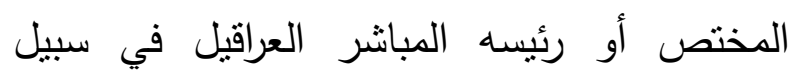
التتفيذ، ومثاله الإيعاز للمنفذ ضده بتهريب أمواله

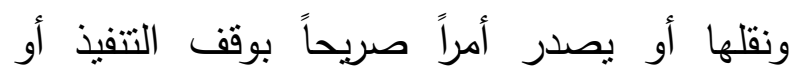

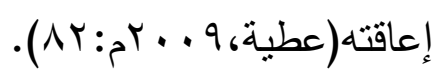

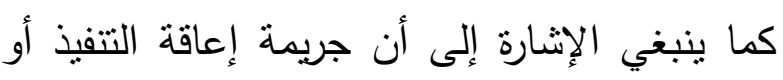

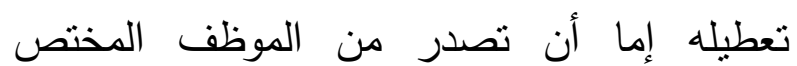
بالتنفيذ، أو من رئيسه المباشر، أو من رئيسه
المماطلة والمراوغة من جانب مأمور التتفيذ صورة من صور منع التنفيذ؟ ذهب جانب من شراح القانون إلى اعتبار التراخي

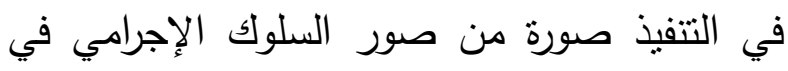

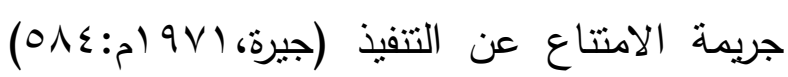

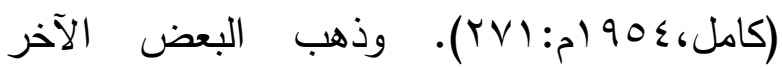
خلاف ذللك، فلا يعتبر التراخي في التتفيذ والتأخر فيه امتتاعاً عن التتفيذ، ويستندون في رأيهم هذا في في فئرافي أن التراخي في التتفيذ وإن كان يدخل في المعنى

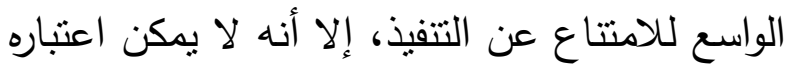

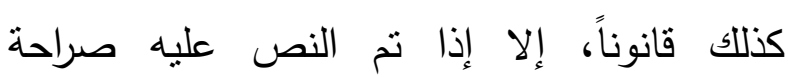
(عبد اللطيف 9VV، (OV) وميزة الرأي الأخير أنه يؤدي إلى عدم مسألة

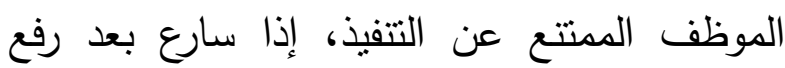
الدعوى الجنائية ضده بتتفيذ الحكم محل الاتهام، إذ إذ الداع يعتبر في هذه الحالة منأخراً في التنفيذ وليس مدتنعاً عiه أما المنظم السعودي فقد حسم هذه المسألة عندما قرر في المادة الخامسة والتسعين من نظام التنفيذ أن" للمتضرر من المماطلة في إجراءات التتفيذ؛ إقامة دعوى في مواجهة المنسبب أمام قاضي التنفيذ

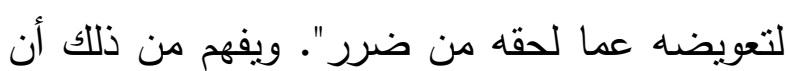

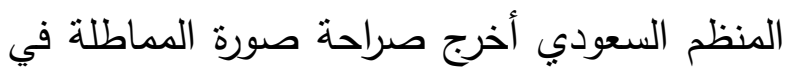
التنفيذ ولم يعتبرها صورة من صور المنع، كما لم يرتب على التأخير في التنفيذ مسؤولية جنائية، وإنما جعل للمتضرر من المماطلة في التنفيذ الحق في إقامة دعوى مدنية أمام قاضي التتفيذ للمطالبة بالتعويض عما لحقه من ضرر. 
وبناء على هذا الأصل العام فإن جريمة منع التتفيذ من الجرائم العمدية، ولا تقوم بالخطأ مهما كانت درجته لعدم ورود ذلك صراحة في نص المادة (^ه) موضوع دراستتا. فالركن المعنوي في جريمة منع التتفيذ يتخذ صورة القصد الجنائي، ولا يكفي لقيام هذه الجريمة توافر القصد الجنائي العام، بل لا بد أيضاً - بالنسبة

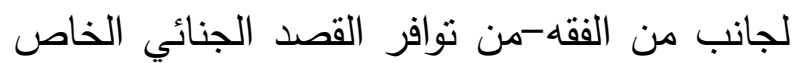
والمتمتل في انصراف نبة الموظف إلى تحقيق نتيجة خاصة، وهي الحيلولة دون تتفيذ حكم قضائي

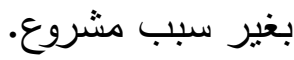
وسوف نتحدث عن عناصر القصد الجنائي العام والقصد الخاص على التقصيل التالي. الفرع الأول عناصر القصد الجنائي العام يلزم لقيام المسؤولية الجنائية أن يحيط الجاني علماً بكل العناصر الأساسية التي تتكون منها الجريمة كما حددها النظام. فيجب إذن أن يحاط علم الجاني لئن بوجود السند التتفيذي، وأن هذا السند واجب التتفيذ لأنه ياخل في اختصاص الموظف. ويستمد الجاني العلم بالاختصاص بالتتفيذ بطريقتين: الأولى: إذا كانت الوحدة التي تم تعيين الموظف بطان فيها تختص أصلاً بتنفيذ السندات التتفيذية، أي أن أن النين طبيعة عملها كذللك، فإن قرار التعيين في هذه الوحدة الإدارية، يفترض علم الجاني بأنه مختص بتنفيذ الأحكام القضائية. الثانية: إذا تم نوزيع الموظف بعد التعيين على التى لاهن

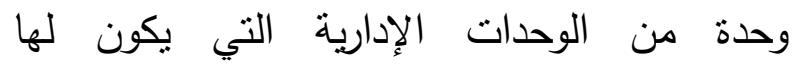

الأعلى، ويجوز فيها الاثترالك من هؤلاء جميعاً لأن الاثتراك متصور في الجرائم الايجابية، خلافاً لجريمة الامتتاع عن التتفيذ التي لا يتصور صدورها إلا من الموظف المنوط به إجراء التتفيذ (عبد التباع

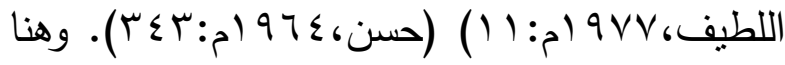
يثور التساؤل حول مسؤولية الرئيس الإداري عن سكوته ووقوفه موقفاً سلبياً مما يقوم به مرؤوسه من الترائ امتتاع عن التنفيذ. إن التفسير الحرفي للمادة (19) يفيد عدم مساءلة الرئيس الإداري للموظف المختص بالتتفيذ عن سكوته عما يقوم به مرؤوسه من امتتاع عن التتفيذ، ذلك أن المادة سالفة الذكر عاقبت الموظف العام ومن في حكمه على "منع التتفيذ أو إعاقته"، ولا تعاقب على عدم استعمال الموظف لسلطته للحيلولة دون وقف تتفيذ الأحكام، وإن كان يمكن مساءلة الرئيس الإداري عن جريمة إعاقة التتفيذ إذا قام بإصدار أمر كتابي أو شفوي بوصفه مستغلاً سلطته

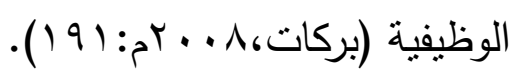

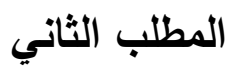

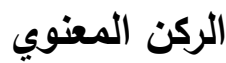

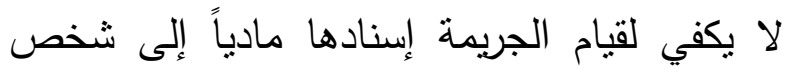

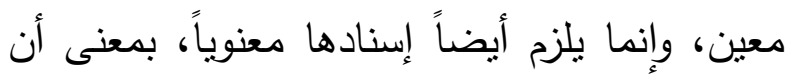
تتوافر بين مرتكب النشاط وبين الجريمة رابطة نفسية. والقاعدة أن الثخص لا يسأل جنائياً عما بأنيه من

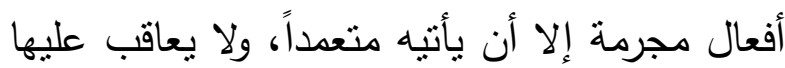
إذا ارتكبها مخطأ، ما لم يكن الثارع قد قرر عقوبة الثهابة

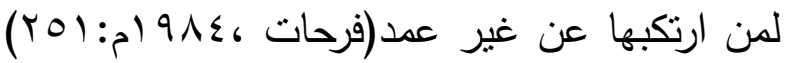


الفرع الثاني

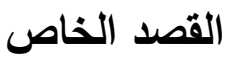

يثور التساؤل حول ما إذا كان المنظم يستلزم للعقاب على هذه الجريمة نوافر قصد خاص لاى الجاني. يتجه جانب من الفقه إلى تطلب قصد خاص، وهذا القصد يتمتل في انصراف نبة الموظف إلى تحقيق نتيجة خاصة، وهي الحيلولة دون تتفيذ الحكم القضائي بدون سبب مشروع، فيكون في هذه الحالة

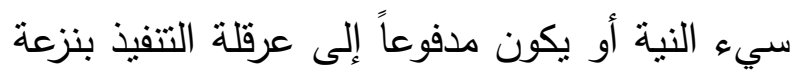

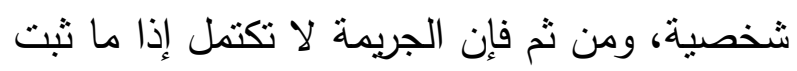
أن الموظف لم يقصد تحقيق هذه النتيجة

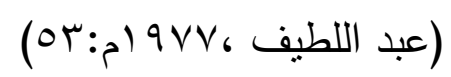
بينما يتجه فريق آخر إلى عدم تطلب قصد خاص لقيام هذه الجريمة، فيكفي بالنسبة لهم توافر القصد الجنائي العام، وحجتهم في ذلك أن القانون يعاقب على الامتتاع عن التتفيذ ذاته دون أن يتطلب حدوث نتيجة لأن النتيجة تختلط مع الفعل، بالإضافة إلى أن النتيجة في هذه الجرائم نتيجة قانونية، تتمثل في الضرر الذي يصيب الدحكوم له له

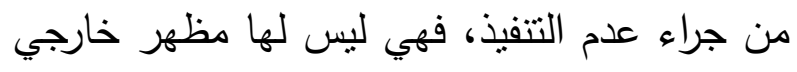
يمكن التحقق من وجوده، هذا إلى جانب أن كل لـ لهن

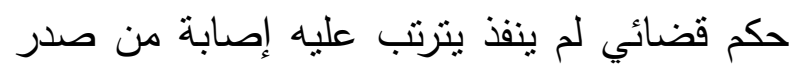

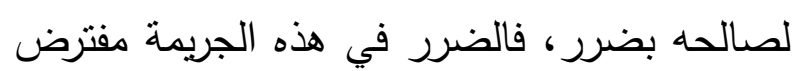

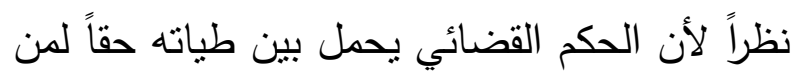

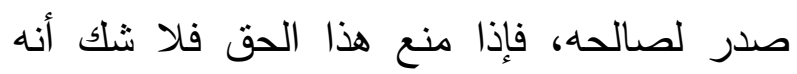

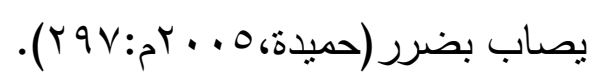
ونميل إلى الرأي الأخير القائل بعدم نطلب قصد

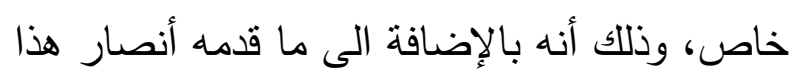

اختصاص بالتتفيذ، بناء على قرار إداري من رئيس العمل، فلا يفترض علم الموظف بالاختصاص إلا بالا لإن

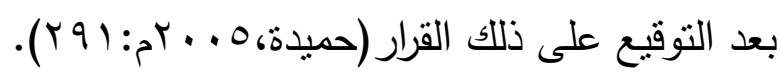
كذلك يجب أن يحاط الجاني علماً بأن امتتاعه عن

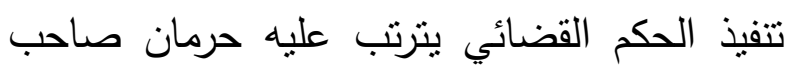

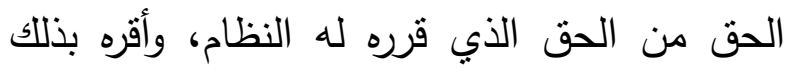

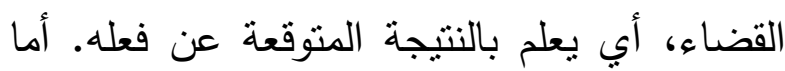

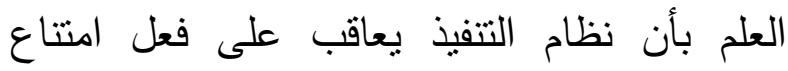
الموظف عن تتفيذ الحكم القضائي فهو مفترض في حق الفاعل فلا يقبل منه الاعتذار بجهل القانون' '. كما يجب أن تتجه إرادة الجاني إلى السلوك الإجرامي المتمنل في الامتتاع، وتتضح إرادة الجاني إلى الجي

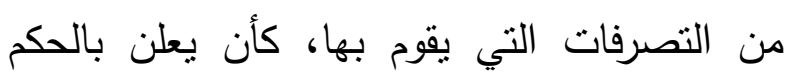

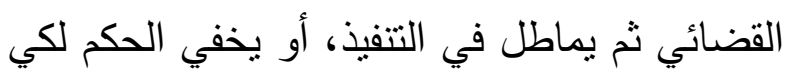
ينكر إعلانه به، أو بطلب من المحكوم له مستندات لا صلة لها بتتفيذ الحكم بقصد عرقلة التتفيذ.

كما يجب أن تتجه إرادة الجاني إلى تحقيق النتيجة، وهي حرمان طالب التتفيذ من الحق الذي قرره له

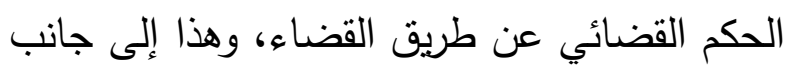

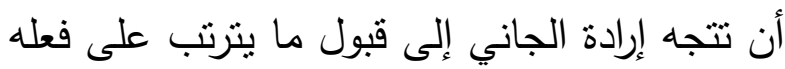

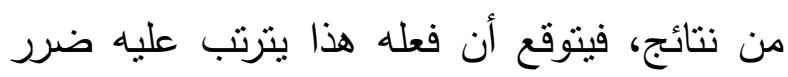
بالمحكوم له ومع ذلك يقبل هذا النوقع إرادياً، نظراً

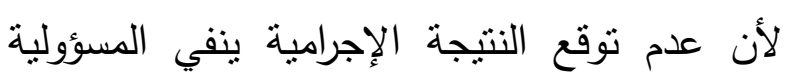

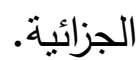

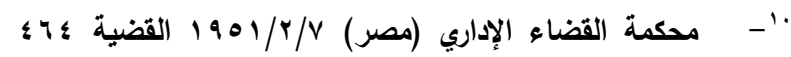

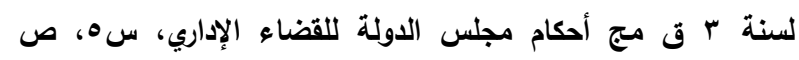

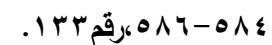


الفرع الاول الجهة المختصة برفع الدعوى الأل تحريك الدعوى الجزائية هو أول عمل إجرائي يتم

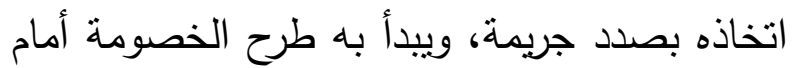

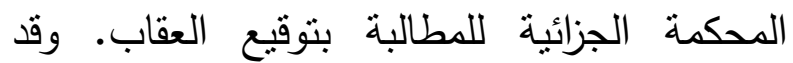
أوضحت المادة (^V) من نظام التنفيذ السعودي الطريق النظامي في تحريك هذه الدعوى، وأن ذلك

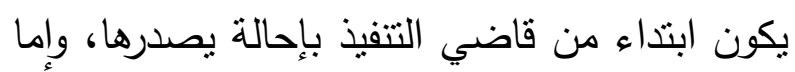
بناء على بلاغ من الذي أصابه الضرر من جراء

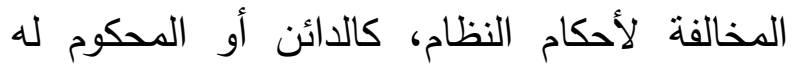
بالتنفيذ المباشر ونحو ذلك. وقد أوضحت اللائحة التتفيذية للمادة (l/Av) بأنه إذا كانت إحالة القضية لهيئة التحقيق والادعاء العام من قاضي التنفيذ بطلب رفع الدعوى العامة، فيتعين إقانتها وإحالة الأوراق للمحكمة المختصة بعد إجراء التحقيق، ولا يجوز والحالة هذه حفظ المعاملة لعدم

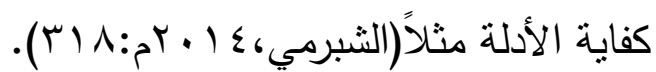
أما بالنسبة لدعوى الحق الخاص المتولد من الجريمة، والذي يصيب المجني عليه وينشأ له حقاً في طلب التعويض، فالأصل أن يطالب الدضرور بهذا التعويض بموجب دعوى مدنية يرفعها أمام

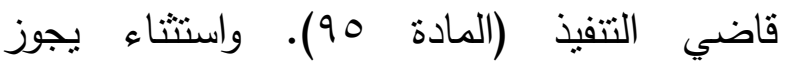
للمضرور من الجريمة المطالبة بهذا التعويض أمام القضاء الجزائي بالتبعية للاعوى الجزائية.

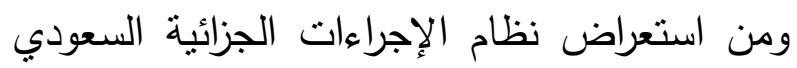

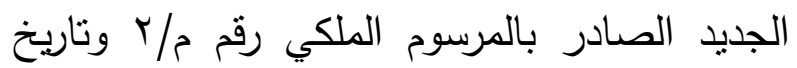

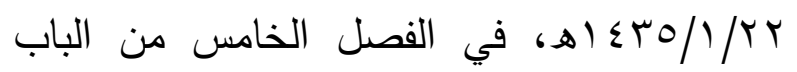

الرأي من حجج وأسانيد، فإن القصد الخاص ينبغي أن يكون واضحاً من عبارة النص، الذي يفيد هذا

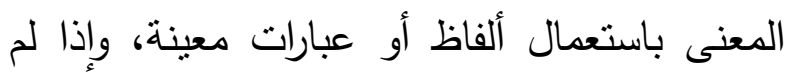
يفصح النص عن تلاك النبة الإجرامية المحددة، وجب الرجوع إلى الأصل والاكتفاء بالقصد العام. كما أن انشتراط القصد الخاص، يتضمن التيسير على المتهم، والتشديد على هيئة الحكم، الأمر الذي لني يؤدي إلى إفلات الكثير ممن يرتكبون هذه الأفعال

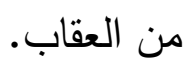
المبحث الثالث

الجواتب الإجرائية والجزاءات المقررة للامتتاع

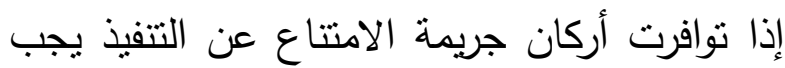

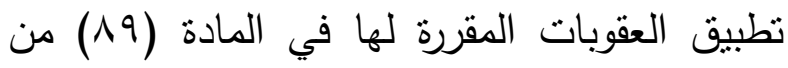
نظام التتفيذ. ولكن قبل الحديث عن العقوبات المقررة للموظف الممتتع عن التتفيذ، يتعين علينا أن نشير إلى مجموعة القواعد التي تحكم طلب إيقاع العقوبة على المتهم والجهة المختصة بمحاكته.

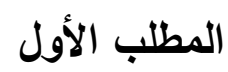
الاختصاص بلعوى منع أو إعاقة التنفيذ جاء في المادة السابعة والثنانين في الفصل الثالث

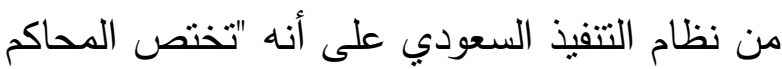
الجزائية بالنظر في إيقاع العقوبات الواردة في هذا النظام، وترفعها هيئة التحقيق والادعاء العام بناء على إحالة يصدرها قاضي التتفيذ أو بلاغ من

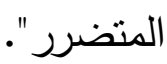
ونتناول فيما يلي دراسة الجهة المختصة برفع

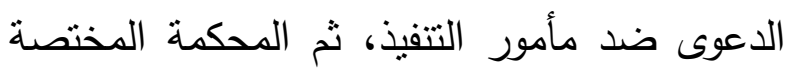

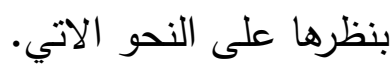


أنه "للهجني عليه أو من ينوب عنه، ولوارثه من بعده، حق رفع الدعوى الجزائية في جميع القضايا الني يتعلق بها حق خاص، ومباشرة هذه الدعوى أمام المحكمة المختصة، وعلى المحكمة في هذه الحالة تبليغ الددعي العام بالحضور ". ولكن يثور التساؤل لمعرفة فيما إذا كان لهيئة

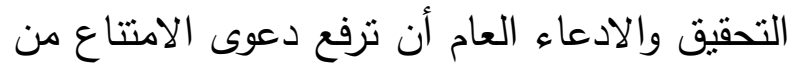

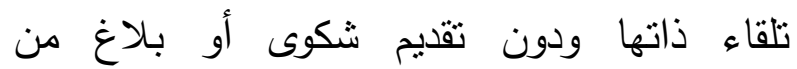

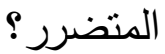
أجابت المادة السابعة عشرة من نظام الإجراءات

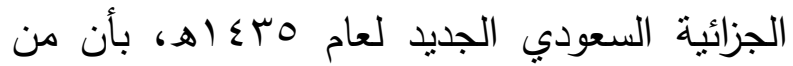
حق هيئة التحقيق والادعاء العام رفع الدعوى الجزائية والتحقيق في الجريمة إذا رأت مصلحة عامة في ذلك. وبناء عليه متى رأت الهيئة أن في تحريك الدعوى العامة مصلحة عامة فإنها يجب أن تباشر في تحريكها، وهذه المصلحة العامة تقديرية

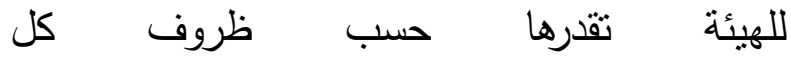

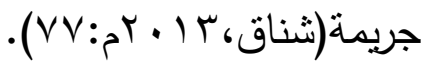

$$
\begin{aligned}
& \text { الفرع الثاني }
\end{aligned}
$$

\section{الجهة المختصة بالمحاكمة}

تختص المحاكم الجزئية بالنظر بجرائم التعزيرات، واستثناء أناط المنظم السعودي الدوائر الجزائية في ديوان المظالم بالنظر في بعض القضايا الجزائية منل جرائم التزوير والرشوة والجرائم المنصوص عنها

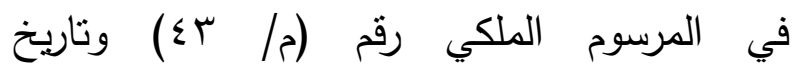

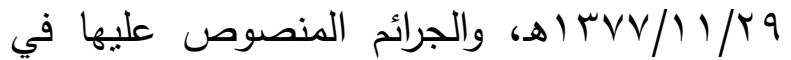
نظام مباشرة الأموال العامة الصادر بالمرسوم

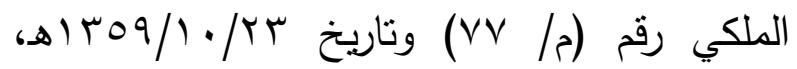

السادس لأحكام الادعاء بالحق الخاص في المواد

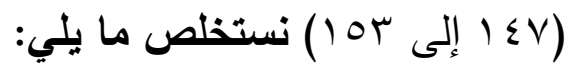
حق من لحقه ضرر من الجريمة هو أو من يحل محله في رفع دعوى الحق الخاص أمام المحكمة

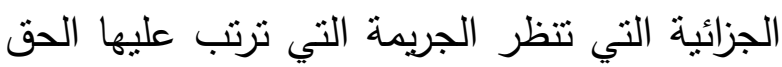

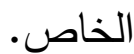
أن هذا الحق غير مقيد بمرحلة معينة تكون عليها الدعوى الجزائية، حتى ولو رفض طلب الدق الخاص أثناء مرحلة تحقيق الجريمة التي سبيت

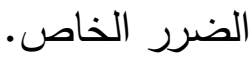
أنه لا اعتبار لقيمة ما يطالب به من حق خاص. وحق المضرور من الجريمة في اللجوء إلى القضاء الجزائي للمطالبة بالتعويض يكون بإحدى وسيلتين: الأولى: إما أن يتدخل أمام القضاء الجزائي أثناء

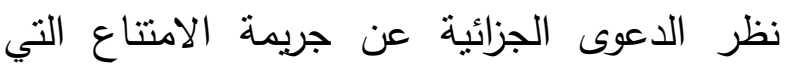
سببت له هذا الضرر والتي إقامتها هيئة التحقيق التشيق

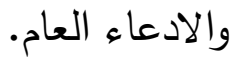
الثانية: أن بطرق المضرور بنفسه مباشرة القضاء الجزائي بطريق الادعاء المبانر ، في الفرض الذي لاني

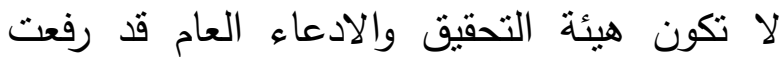
الدعوى بشأن الجريمة التي وقعت، وبالتالي فإن الادعاء المباشر من المضرور يعد وسيلة من

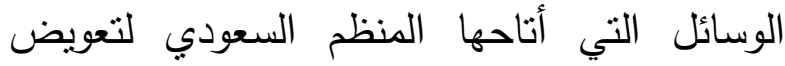
المجني عليه عن الضرر الذي ناله من ارتكاب الجريمة، والذي يترتب عليه تحريك الدعويين

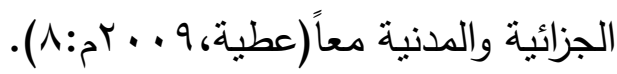
كما أن المادة السادسة عشرة من نظام الإجراءات مطاعلهات

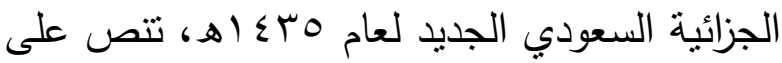




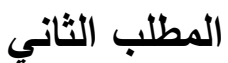

العقويات المقررة لجريمة الامتناع عن التنفيذ

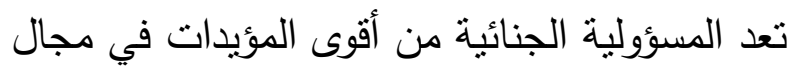

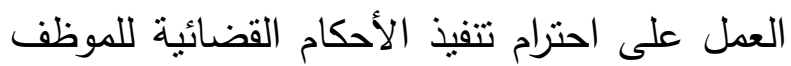

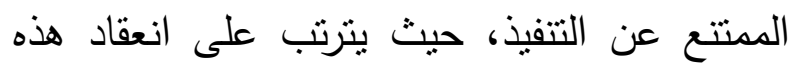
المسؤولية فقدانه حريته وعزله من وظيفته، ولا شك أن ذللك يحمل الموظف على الاحترام الكامل للأحكام القضائية، والمسارعة إلى تتفيذها. وطبقاً

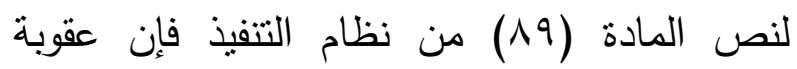
الامتتاع عن تتفيذ الأحكام هي السجن لمدة لا تزيد عن سبع سنوات، وتعد الجريمة من الجرائم المخلة

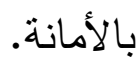

وقد اكتفى النص بوضع حد أعلى للسجن، وهو

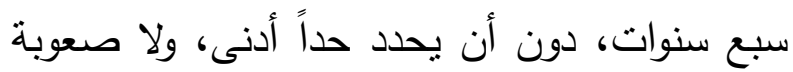

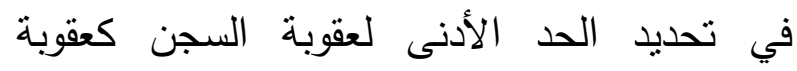
تعزيرية في الثريعة الإسلامية، فهي يوم واحد.

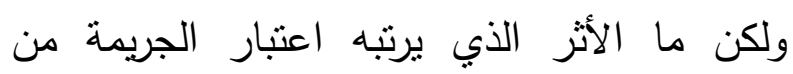

الجرائم المخلة بالأمانة؟ الانج

إن اعتبار الجريمة من الجرائم المخلة بالأمانة يترتب عليه الحرمان من العودة إلى الوظيفة العامة

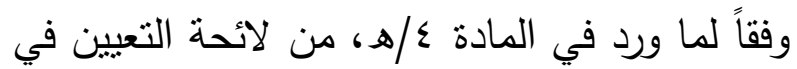
الوظائف العامة الصادرة برقم /

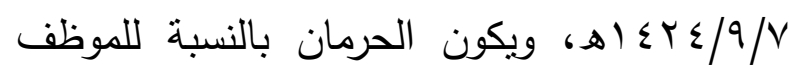
العام المحكوم بجريمة من الجرائم المخلة بالأمانة لمدة ثلات سنوات، حيث يشترط لدخول تلك الوظيفة

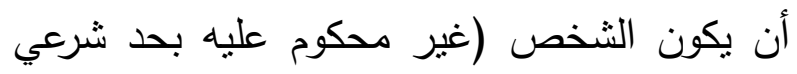
أو بالسجن في جريمة مخلة بالثرف أو الأمانة، حتى يمضي على انتهاء تتفيذ الحد أو السجن ثلاث
وجرائم انتحال صفة رجل السلطة العامة الوارد بنظام عقوبات انتحال صفة رجل السلطة العامة

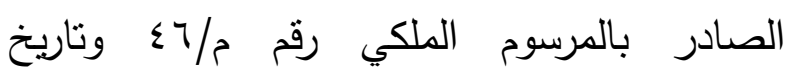

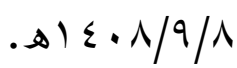
ومع صدور نظام القضاء الجديد الصادر بالمرسوم الملكي VN/P تاريخ اختصاص الفصل في دعاوى الدق العام للمحاكم

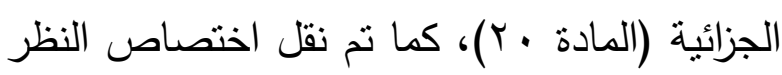
في الجرائم التي تتظر من الدوائر الجزائية في ديوان المظالم إلى القضاء العادي بحيث نتولى الدحاكم

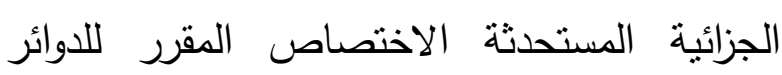

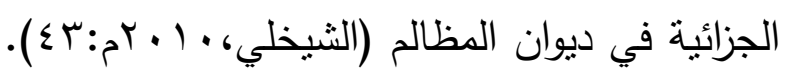
فقد نصت المادة (Y) (Y) من نظام الاجراءات

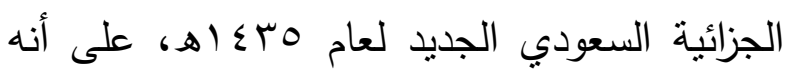

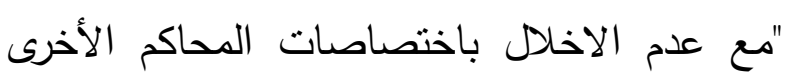
تختص الدحكمة الجزائية بالفصل في جميع القضايا

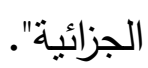

وانسجاماً مع هذا التطور التشريعي في تتكيل السلطة القضائية واختصاصها، فقد قررت المادة (Av)

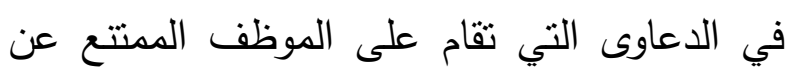
تتفيذ الأحكام القضائية هي المحاكم الجزائية.

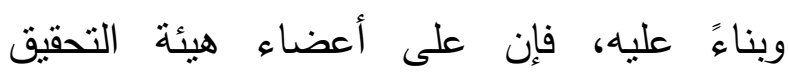

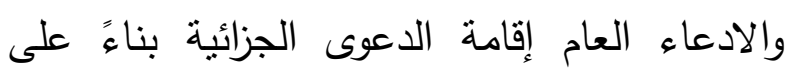
إحالة من قاضي التنفيذ إلى المحكمة الجزائية التي لألئي لها النظر في الدعوى وفي إيقاع العقوبات المقررة

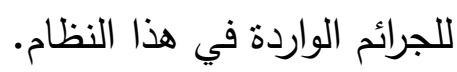


ץ-إذا صدر بحقه حكم شرعي مكتسب للصفة القطعية بارتكاب موجب القصاص في النفس. ץ-إذا صدر عليه حكم من جهة قضائية مختصة مكتسب للصفة القطعية مصرح فيه بالإدانة والحكم بالعقوبة في الجرائم التالية: (الرشوة - التزوير الاختلاس - التهريب أو الترويج أو المتاجرة بالمخدرات أو المسكرات). ع-إذا حكم عليه بعقوبة السجن لمدة تزبد على

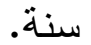
ولا يؤثز وقف تتفيذ العقوبة الأصلية المحكوم بها

$$
\text { على تطبيق هذا الحكم". }
$$

فالمادة الثانية عشر من لائحة انتهاء الخدمة قيدت حالة فصل الموظف في بعض الجرائم التعزيرية التي بحكم عليه فيها بالسجن. وبناء عليه، لا مجال لعزل الموظف الممتتع عن التنفيذ من وظيفته في ظل لائحة انتهاء الخدمة إلا في حالة أن بتذخل المنظم بتعديل تشريعي، إما لنص المادة (^9) من نظام التنفيذ بحيث تصبح العقوبة السجن والعزل من الوظيفة، أو بإضافة جريمة منع التتفيذ إلى قائمة الجرائم الواردة في الفقرة الثالثة من المادة الثانية عشر من لائحة انتهاء الخدمة وهي (الرشوة - التزوير -الاختلاس التهريب أو الترويج أو المتاجرة بالمخدرات أو

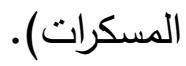
وبخلاف ذلك لا نرى سبيلاً إلى عزل الموظف من وظيفته إلا إذا حكم عليه بعقوبة تزيد عن السنة،

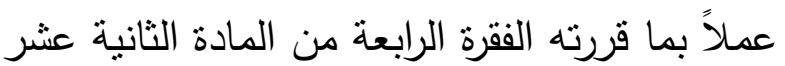

سنوات على الأقل). ولكن هل بترتب على اعتبار الجريمة من الجرائم المخلة بالأمانة عزل الموظف

حكماً من وظيفته؟

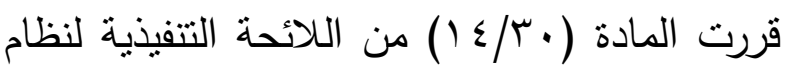
الخدمة المدنية الصادر بالمرسوم الملكي رقم

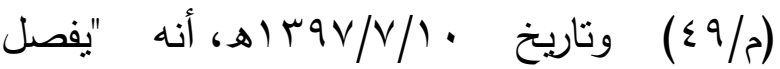
الموظف بقوة النظام في الحالات التالية: أ-الحكم بالإدانة في حد شرعي. ب-الحكم بالسجن في جريمة مخلة بالثرف والأمانة.

ج-الحكم بالسجن مدة تزبد عن السنة.

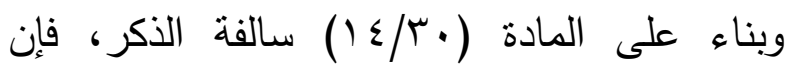
المحكوم بالسجن في إحدى الجرائم المخلة بالثرف والأمانة يفصل من وظيفته بقوة النظام. غير أن لائحة انتهاء الخدمة الصادرة بموجب قرار

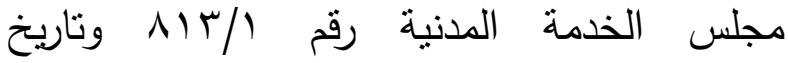

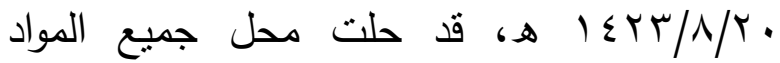
الواردة باللائحة التنفيذية لنظام الخدمة المدنية من

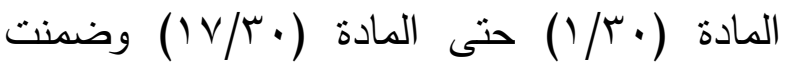
اسباباً لفصل الموظف من وظيفته ليس من بينها الجرائم المخلة بالثرف والأمانة. فقد جاء في المادة الثانية عشر من لائحة انتهاء الخدمة "يفصل الموظف بقوة النظام ويعتبر الفصل لأسباب تأديبية في الحالات الآتية: 1-إذا صدر بحقه حكم شرعي من جهة قضائية مختصة، مكتسب للصفة القطعية، مصرح فيه بثبوت ارتكابه موجب حد من الحدود الثرعية، ومعاقبته بالجزاء حداً. 
ثالثاً: لم يضع المنظم معياراً محدداً يمكن من خلاله معرفة الوقت المناسب للتنفيذ، والذي بانقضائه يصبح الموظف ممثتعاً عن التتفيذ، كما لا يوجد معيار منضبط يحدد ذلك. رابعاً: أستبعد المنظم من نطاق المسؤولية الجزائية حالات التأخير في التنفيذ، ورتب على هذه الحالة مسؤولية مدنية عن الأضرار التي تترتب على التأخير عن التنفيذ ينظرها قاضي التنفيذ. خامساً: يفهم من نص المادة (1 (1) من نظام التنفيذ شموله للموظفين الذين يعوقون التنفيذ لمصلحة طالب التنفيذ وليس للجهات الحكومية المنفذ عليها، أو بمعنى آخر أنه لا يطبق في حالة كون الجهة الحكومية أحد أطراف القضية المتخاصم فيها، وإنما

كجهة تقوم بالتتفيذ فقط.

واستناداً لما سبق، يوصي الباحثان بما يلي: أولاً: ضرورة مد نطاق التجريم الوارد في المادة (^9) ليشمل إلى جانب حالة الامتتاع العمدي حالات التأخير العمدي في التفيذ، وذلك حتى لا يمنح مأموري التنفيذ الرخصة في التأخير والتراخي في التنفيذ، بل ويجعلهم - إذا ما رغبوا في تعطيل تتفيذ الأحكام -بنتهجون أسلوب التأخير والتباطؤ بدلاً من الامتناع الصريح عن التنفيذ، والذي يخضعهم لنطاق التجريم الوارد في المادة (^9) من الن نظام التنفيذ.

ثانياً: ضرورة مد نطاق التجريم ليشمل الموظف

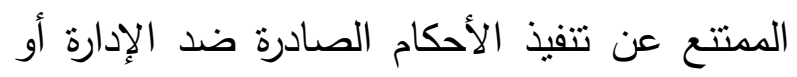
إعاقتها بشكل يكفل احترام أحكام القضاء وسيادة
من لائحة انتهاء الخدمة، ولكن هنا ليس لأن جريمته مخلة بالأمانة وإنما لاعتبار آخر . الخاتمة تتاول الباحثان في هذه الدراسة موضوعاً في غاية الأهمية، يتعلق ببيان المسؤولية الجنائية لمأمور التنفيذ في نظام التنفيذ السعودي الصادر بالمرسوم

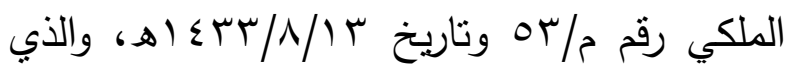
أخضع الموظف العام المكلف بالتتفيذ للمساءلة الجنائية. وقد خلصت الدراسة إلى جملة من النتائج يبرز الباحثان أهمها على النحو التالي: أولاً: أظهرت الدراسة توسع المنظم السعودي في نطاق التجريم، سواء من حيث الأشخاص المخاطبين بالنص أو المحل الذي يقع عليه. فمفهوم الموظف العام ليس مقصوراً على الموظف العام

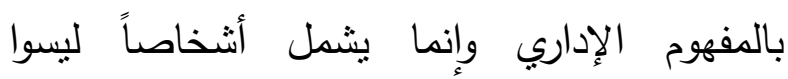
موظفين بحسب هذا المفهوم، وهم المكلفون بإدارة المرافق، كما هو الحال في المشاريع المشتركة والمرافق التي تديرها الدولة بنظام الاستغلال غير المباشر وغيرهم. كما توسع النظام في ما يعد سنداً تتفيذياً، فبعد أن كانت السندات التنفيذية محصورة في سندات التتفيذ القضائية أضيف إليها سندات التتفيذ غير القضائية، وهي التي يعطيها النظام قوة السند التتفيذي. ثانياً: جرم المنظم امتتاع الموظف المختص بالتتفيذ عن تتفيذ الأحكام والسندات التتفيذية، بصرف النظر عن حدوث نتيجة إجرامية معينة كأثز لهذا الامتتاع. 
ثالثاً: إن عبارة "تعد من الجرائم المخلة بالأمانة" وأخيراً يمكنا القول بأن المأمور هو العامل الوحيد

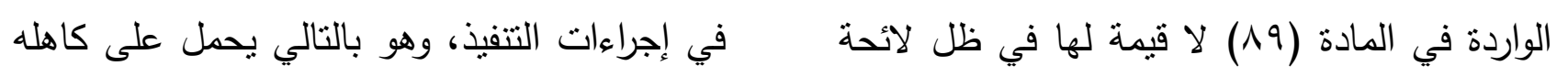

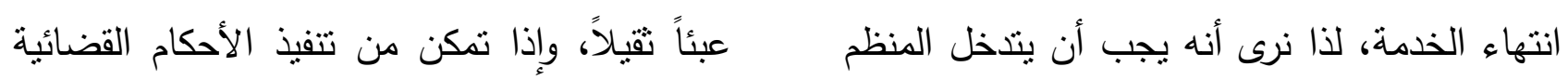

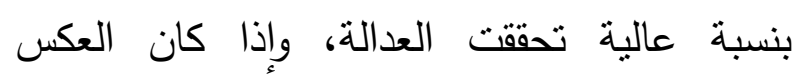

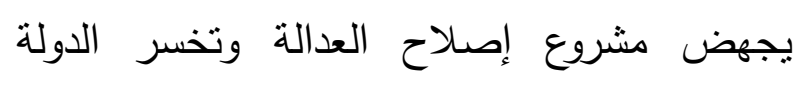

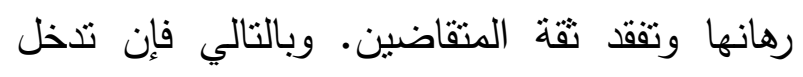
المنظم السعودي من خلال إثارة المسؤولية الجنائية للموظفين العموميين المختصين في التتفيذ الذين

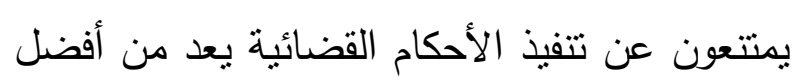
الوسائل التي تكفل احترام الأحكام القضائية، وتفرض الالتزام بتتفيذها.

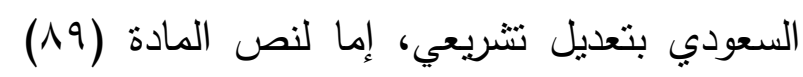

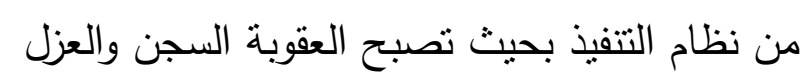
من الوظيفة، أو بإضافة جريمة منع التنفيذ الى نى

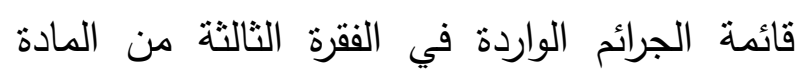
الثانية عشر من لائحة انتهاء الخدمة.

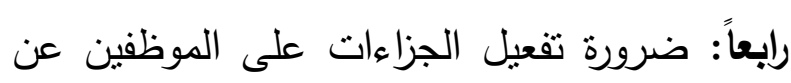
الانحراف والتعسف في إجراءات التتفيذ، وضرورة

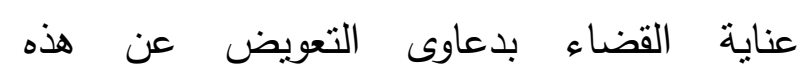
الانحرافات. 
عطية، حمدي رجب (9 . . . Fم) الادعاء المباشر ضد الموظف العام في

عوض، محمد محيب الدين (9 19 أ اله) الرشوة شرعاً ونظاماً موضوعاً وشكلاً، طا، مطابع الولاء الحديثة.

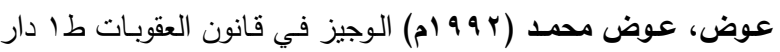
الكتب المصرية القاهرة. فرحات، محمد نعيم ( 9 (9 ام) شرح القسم الخاص في التشريع الجنائي الإسلامي، مكتبة الخدمات الحديثة، جدة.

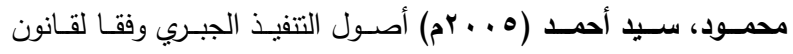

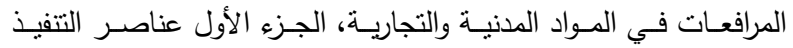
الجبري ومقدماته، الطبعة الأولى. والي، فتحي (ب9 9 (م) التتفيذ الجبري في المواد المدنية والتجارية، دار

النهضة العربية.

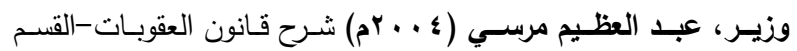
الخاص -الجزء الأول، طץ دار النهضة العربية، القاهرة. ثانياً: الرسائل العلمية وإلمقالات: 1-رسائل الماجستير والدكتوراه :

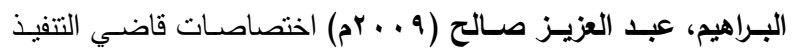
وتطبيقاتها في النظام السعودي، رسالة ماجستير - قسم العدالة الجنائية جامعة نايف العربية للعلوم الامنية .

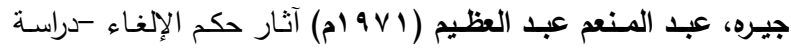
مقارنة في القانون المصري والفرنسي، رسالة دكتوراه، جامعة القاهرة.

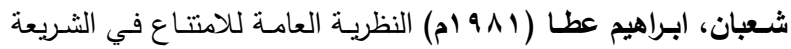
والقـانون الجنـائي الوضـعي، (رسـالة دكتوراه) مقدمـة الـى كليـة الحقوق

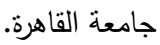

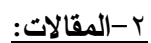

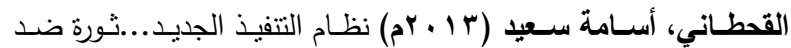
المحتالين، الوطن اون لاين. http://alwatan.com.sa/Articles/Detail.aspx?ArticleID=1 $\underline{3886}$ الفـالح، بندر بـن عبد الرحمن (r ا • rم) تتفيذ الأحكام الصـادرة عن

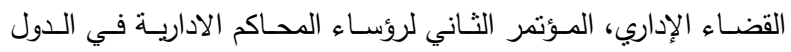
العربية، المنعقد في أبو ظبي، الامارات العربية المتحدة، الاه-ب ا ايلول.

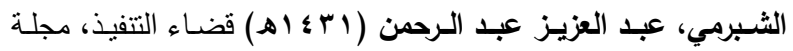

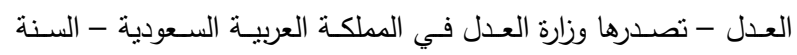

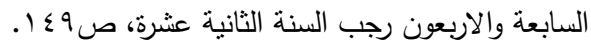
حسن، عبد القتاح (ع ج 9 ام) تعطيل تتفيذ الحكم القضائي، مجلة العلوم

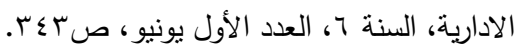

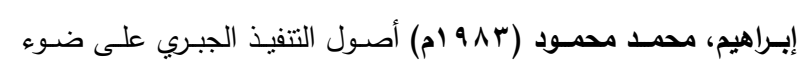
المنهج القضائي، دار الفكر العربي، القاهرة.

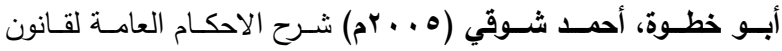
العقوبات، القاهرة، دار النهضة العربية.

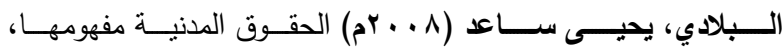

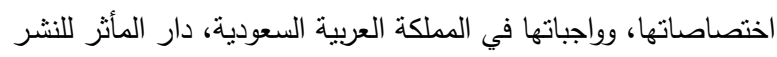
المدينة المنورة. القصـاص، عيــ محمـد (1 . . rم) المسؤولية عن التتفيذ الجبري، دار

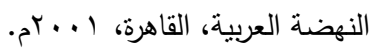
الصيفي، عبد الفتاح مصطفى (• ( • rم) الأحكام العامة للنظام الجنائي في الثريعة الإسلامية والقانون، الإسكندرية، دار المطبوعات الجامعية.

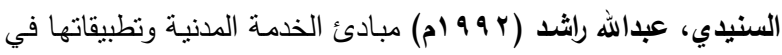
المملكة العربية السعودية، طه، الرياض، مطابع الفرزدق التجارية.

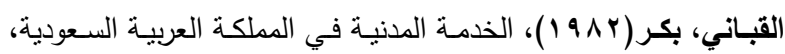

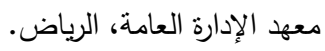

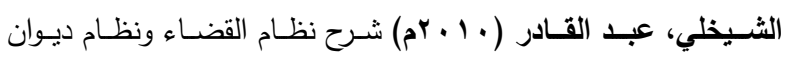
المظالم، مطبوعات شركة بن محفوظ للمحاماة، الطبعة الاولى. الثبرمي، عبد العزيز عبد الرحمن (؛ ا ـ بام) شرح نظام التنفيذ مدار الوطن للنشر الطبعة الأولى. الطنـاحي، محمـود محمـود (^ + • rم) المقومـات الموضـوعية والثـكلية للسند التتفيذي، دار الفكر والقانون بالإسكندرية، م م. . rم. الطماوي، سليمان (7ه ا9 ام) مبادئ القانون الاداري نظريـة المرفق العام

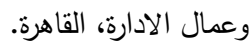
الليثي، محمد سعيد (9 . . بم) امتتاع الإدارة عن تتفيذ الأحكام الإدارية الصادرة ضدها، دار الفكر والقانون للنشر والتوزيع.

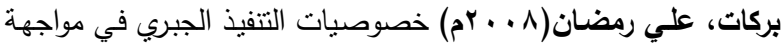

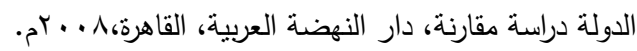
جميعي، عبدالباسط (1) 94 (م) " التتفيذ"، دار الفكر العربي.

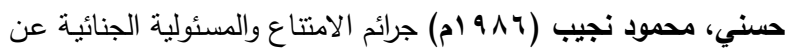

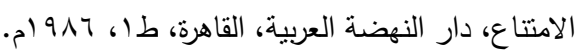
حميدة، عبد الله حسين (ه . . بم) المسؤولية الجنائية للموظف للامتتاع

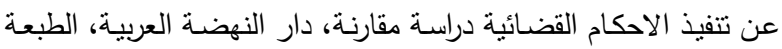
الاولى.

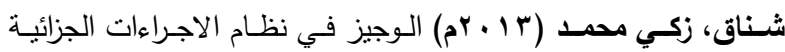
السعودي، دار حافظ للنشر والتوزيع، جدة.

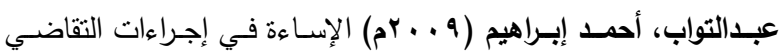

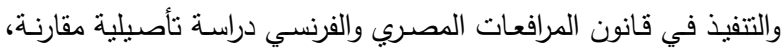
دار الجامعة الجديدة للنشر. 


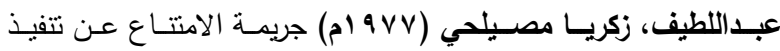

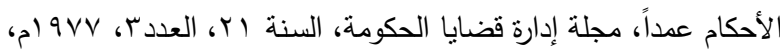

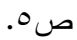
كامل، حسن(؛ 9 (م) أحكام الإلغـاء، مجلة القانون والاقتصـاد، عدد

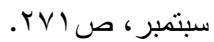




\title{
Criminal Liability of Enforcement Officer under the Saudi Law
}

\author{
Moustafa Bitar \\ Hesham Awad
}

\begin{abstract}
The study aims to shed light on the crime of preventing the execution of judgements through the statement of preliminary issues relating to the crime and the penalties prescribed in the Saudi Execution Law issued by the Royal Decree No. M / 53 of 13/8/1433, which is subjected by the public official in charge of the execution of criminal responsibility. The study addresses the scope of the bailiff responsibility, the statement of the multiple cases that can be carried out by the criminal behavior, and the juridical point of views concerning them. The study also addresses the presuppositions of this crime, both in terms of people concerned by the text and what is considered as an executive support. In addition, the study reviews the cases of criminal activity, the outcome of the crime and it's extent and its degree of obligation in terms of responsibility, as well as the cases that prevent the execution which have not been mentioned in the text, and that are concerned by the provisions of the law.

In the end, the study addresses the penalties prescribed for the offense and their suitability, as well as the set of rules that govern the application of the sentence on the accused and the competent authority to judge him.
\end{abstract}

